\title{
Behavior Of Reinforced Concrete T. Beams With Welded Mesh Reinforcement Under Repeated Load
}

\author{
Dr. Aly Abdel-Zaher Elsayed * \\ * Asso . prof. Civil Engineering Department, Assiut University, Assiut, Egypt.
}

\begin{abstract}
This investigation concerned with the use of steel bars as orthogonal reinforcement for reinforced concrete beams known as mesh reinforcement for beam construction. In practice most beams are designed with only tension reinforcement (singly reinforced). However, in certain situations it might be necessary to design beams with both tensile and compression reinforcement (doubly reinforced). For example when beam cross section is limited because of architectural or other considerations, it may happen that the concrete cannot develop the compression force required to resist the given bending moment in some cases if a beam is designed with only tensile reinforcement, the section may become over-reinforced, which is neither desirable nor acceptable by most codes of practice, in situations the section must also be designed as doubly reinforced.

The aim of this study is to benefit from using of welded mesh (W.M.\#) reinforcement in design of reinforced concrete beams with both tensile and compression reinforcement. For these reason SIX R.C. beams prepared and casted having over, balanced and under, Percentage of main steel reinforcement. Also using welded mesh (W.M.\#) reinforcement equal to balanced and under reinforcement and all beams tested under repeated loading having $80 \%$ from ultimate static load was reached from previous research (13) taking into account the \% of steel reinforcement in reinforced concrete sections at beams,. The results of this research were given to know the behaviour of this type of beams and the role of welded mesh (W.M.\#) reinforcement in design of R.C. beams exposed to very high repeated loading.
\end{abstract}

\section{Introduction}

The influence of repeated loading on the distribution of bond and steel stresses and slip along the bond length can be calculated by the method of stepwise integration Franke. (1976)

Repeated loads (it is meant high cycle load) in the working load range cause an increase in slip between steel and concrete, because of creep of concrete under ribs. The slip $S_{n}$ expected after a certain number of load cycles $\mathrm{n}$ can be calculated according to Franke. (1976) from the initial slip $\mathrm{S}_{\mathrm{o}}$ by:

$$
\mathrm{S}_{\mathrm{n}}=\mathrm{S}_{\mathrm{o}}\left(1+\xi_{\mathrm{n}}\right)
$$

The deformation coefficient $\xi_{\mathrm{n}}$ for repeated loading is given by:

$$
\xi_{\mathrm{n}}=(1+n)^{\eta}
$$

With $\eta \cong 0.105, \eta$ is little influenced by concrete quality or bar diameter.

$\xi_{\mathrm{n}} \sim(3.3)$ for $\mathrm{n}=10^{6}$ load cycles . It is reasonable to assume, that even after a long time the slip increase is not bigger than after $10^{6}$ load cycles. Rehm. \& Eligehausen. (1977).

The local increase of the relative deformations between steel and concrete causes a redistribution of the forces within a given anchorage length, the upper or lower load during cycling was 0.4 or 0.15 -times respectively, the pull-out load. At first loading the highest bond stresses occurred at the beginning of the anchorage with increasing number of load cycles the load transfer was shifted towards the end of the bond length and after $\mathrm{n}=5 * 10^{5}$ load cycles the bond stresses were nearly evenly distributed.

Bond is directly related to strain level; most tests have been performed under stress control. While in some tests only a few load cycles were applied, which did not cause a bond failure, others were performed until fatigue failure of bond occurred. The limit between low cycle fatigue (high load intensity but low number of cycles) and high cycle fatigue (high number of cycles but low load intensity).

Tests with a relatively small number of load cycles $(<\sim 100)$ were performed by Rehm, (1961), Bresler \& Bertero (1968), Goldfain, (1971), Edwards \& Yannopoulos (1978), Urban (1980) and Eligehausen, Bertero \& Popov (1982). The relatively information can be summarized as follows:

1. The higher the load amplitude the larger the additional slip, especially after the first cycle.

2. The total slip increase is due to the increase of residual slip.

3. It is observed that the slip increase is almost stabilized after a few cycles only in analogy to a strainhardening system. However, in other tests no stabilization of slip was found up to $10^{6}$ load cycles. 
4. When loading a bar to an arbitrary bond stress or slip value and unloading to zero, the monotonic bond stress-slip relationship is for all practical purposes reached again during reloading. This behaviour is also valid for a larger number of unloading, provided no bond failure occurs during cyclic loading.

5. The stress transfer from steel to concrete (bond resistance) along an embedded bar at any given stress level is influenced by the previous stress history. A given maximum peak stress level in steel reinforcement reduced the stress transfer effectiveness at lower stresses in subsequent cycles. This deterioration of stress transfer is usually more pronounced than the reduction of stress transfer produced by a small number of repetition of load cycles with constant peak stress

Rehm. \& Eligehausen. (1977, 1979), Summarized that, for repeated loading test the smaller the load amplitude the greater number of cycles up to bond failure. A decrease of upper load has the same favorable effect on service life as an increase of lower load. This means that no fatigue bond failure will occur during several million load reversals if for the usual anchorage lengths required for reinforcing bars the upper load is smaller than the load corresponding to about 50 percent of the static strength.

Load cycling increases the slip of the free bar end. The slip increment is greater for loads (amplitude) over the fatigue strength of bond. Repeated load accelerates the slip between steel and concrete compared with a sustained load.

If no fatigue failure of bond occurs, repeated loading do not negatively affect the local bond stress-slip relationship near ultimate load compared to static loading

The anchorage conditions are different for welded mesh fabric than for bars. The maximum allowable diameter of the wires is only $12 \mathrm{~mm}$ to $16 \mathrm{~mm}$, their spacing is usually $100 \mathrm{~mm}$ or $150 \mathrm{~mm}$ resp., and welded cross bars are present along the anchorage length.

In general, wires with high bond used for producing fabric reinforcement must meet the same requirements for the deformation geometry as reinforcing bars of the same diameter when the welds are taken into consideration in the strength of anchors, each welded nodes must be able to resist anchors force according to CEB-FIP Manual (1979) (11) .

The behavior of deformed welded wire fabric under static and cyclic loading tests on T-beams was study by Attiogbe. (1988).The shear reinforcement used in their tests is consisted of single sheet of welded wire fabric designed to replace an arrangement of conventional single-leg stirrups. They concluded that the deformed welded wire fabric offered a slight improvement of the crack over U-shaped or single-leg stirrups. The anchorage conditions are different for welded mesh fabric than for bars.

The pull-out study by Ayyub, Bilal M, (1994) showed that after the bond between longitudinal wires and concrete failed, the specimens resisted additional loads due to the anchorage effects of transfers wires and shear strength of welds. This increase in bond strength is depending upon the type and arrangement of longitudinal and transverse wires.

Griezic,et al- (1994.) demonstrated that the use of welded wire fabric resulted in better diagonal crack control and enabled large strains to be developed in the stirrups.

The ACI Building Code (1995) and AASHTO Bridge Code (1994) requirements for side-face reinforcement are meat to control flexural cracking in the webs of large concrete beams and may not provide adequate diagonal crack control for certain exposure conditions.

The ACI Building Code and AASHTO Bridge Code adopted a procedure in which the amount of sideface reinforcement depends only on the member depth, except that it need not exceed 1.5 of the flexural tension reinforcement.

The Canadian Concrete Code (CSA A23.3) (1994). require side- face reinforcement ratio (steel area to - concrete area ratio) of 1.0 percent on each side of beam. The Canadian Highway Bridge Code (CHBDC) (1996) requires reinforcement with an area equal to 1 percent of total web area, distributed over 70 percent of the web depth, that results in a minimum of 1.4 percent longitudinal reinforcement in the effective zone . In calculating the required area of reinforcement, the width of the web need not be taken greater than $250 \mathrm{~mm}$ as the side- face reinforcement is assumed to act as skin reinforcement in wider members.

S.Prathima, P. Jaishankar (2015), demonstrated that the use of Wire mesh as a form of reinforcement that differs from conventional reinforcement. Primarily by the manner in which the reinforcing elements are dispersed and arranged. The well distributed and aligned reinforcement has made wire mesh to behave like steel plates. As concrete is weak in tension the tensile stresses in flexural member is resisted by steel reinforcement. Test results clearly indicate that the use of wire mesh layers as an additional reinforcement significantly enhances the flexural strength, cracking behaviour and energy absorption capability.

In this research the maximum used diameter of the wires are 10 and $12 \mathrm{~mm}$, spacing $50 \mathrm{~mm}$ Welded cross bars $10 \mathrm{~mm}$ diameter are present along the anchorage length and beams spans every $200 \mathrm{~mm}$.

The test results show that the use of wire mesh with closely spacing provides the higher energy absorption capacity and flexural strength and decreases the crack width among those concrete beam specimens. 


\section{Experimental work}

Six full-size T-beams were tested under repeated loading. These beams were identical with beams tested under static loading in Ref. (13).The beam dimensions, reinforcement and load arrangement are shown in table (1) and Fig. (1). Four different percentages of main longitudinal tension steel reinforcement bars were used, in addition and two arrangements of welded mesh (W.M.\#) reinforcement were used.

Beams $\left(\overline{\mathrm{A}}_{1}, \overline{\mathrm{A}}_{2}, \overline{\mathrm{A}}_{3 \circledast \mathbb{\Theta}}\right.$, and $\left.\overline{\mathrm{A}}_{4}\right)$ had deformed wires bent to form U-stirrups, $10 \mathrm{~mm}$ in diameter at a spacing of $200 \mathrm{~mm}$. The stirrups were welded with longitudinal reinforcement in tension and compression zones. The deformed wires mesh(W.M.\#) had longitudinal reinforcement spacing every $50 \mathrm{~mm}$ from $12 \mathrm{~mm}$, and $10 \mathrm{~mm}$ diameter for beams $\left(\overline{\mathrm{A}}_{5} \#\right)$ and $\left(\overline{\mathrm{A}}_{6} \#\right)$ respectively. All beams had the same vertical deformed wires, $10 \mathrm{~mm}$ in diameter at spacing of $200 \mathrm{~mm}$.

The flange of each beam was reinforced with a deformed wire diameter $9.5 \mathrm{~mm}$ and $200 \mathrm{~mm}$ square grid. Tension tests were conducted on three representative samples of the bars used as vertical and horizontal reinforcement. The results of these tests are presented in table (2).

Concrete-mix was designed to produce, concrete having a 28 days cubic strength of about $300 \mathrm{~kg} / \mathrm{cm}^{2}$. The mix proportion by weight was as follows:

Cement: sand: gravel: w/c

$$
1: 1.39: 2.78: 0.5
$$

The produced concrete had a cement content and water of $400 \mathrm{~kg} / \mathrm{m}^{3}$ and $200 \mathrm{liter} / \mathrm{m}^{3}$ respectively.

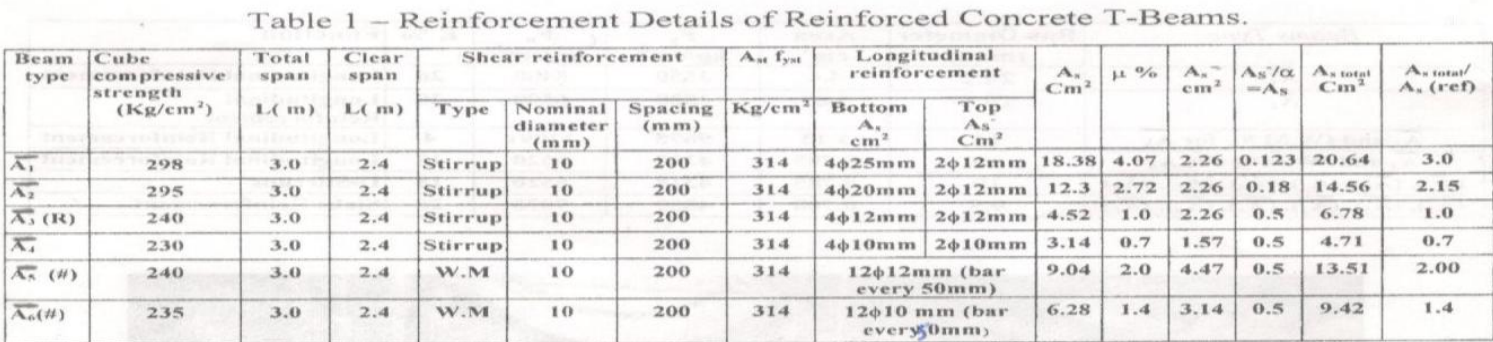

R (Reference Beam) \# (W.M) Welded Mesh

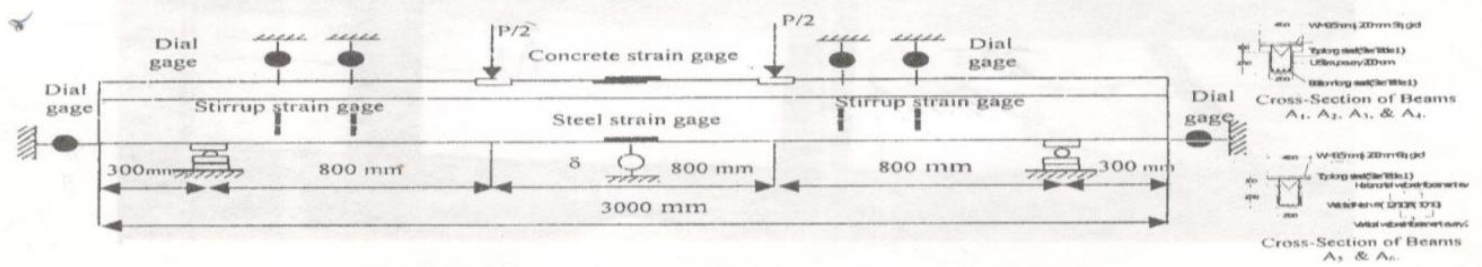

Fig. (1): Beams Dimensions and Test Arrangement

\section{Testing of Beams (Test setup, Instrumentation, and Test procedure)}

A schematic diagram of the test setup is shown in Fig. (2). the beams were simply supported over a clear span of $2.4 \mathrm{~m}$ and were tested under two third-point loading. The available testing machine (EMS 60 tons $\mathrm{p}_{\mathrm{u}}$ ) was used in all tests, see Fig. (2).

The six beams were tested under repeated loading having a value $80 \%$ of ultimate static load $\left(\mathrm{P}_{\mathrm{us}}\right)$ which were recorded in previous research (13).The same gauges arrangements were also chosen for the fatigue tests. The applied load was transmitted to the tested beam through a tar having a weight of 1.4 ton which consider the minimum load level. The load was applied in increments. After each increment every 2.0 load was kept constant between two successive increments for a period of 15 minutes. Readings of the strain gauges, dial gauge and crack propagation were recorded for each beam. The maximum load of the fatigue load function was the $0.8 \mathrm{pus}_{\text {us }}$ load. The repeated loading was applied for half million of load cycles. Recording of deformations were carried out at every $10 \times 10^{3}$ load cycles up to $50 \times 10^{3}$ repetitions. Afterwards, deformations were recorded every $50 \times 10^{3}$ load cycles. Maximum readings of strain gauges deflect meters and crack propagation recorded at the end of specified number of load cycles, without interrupting the loading process.

At the end of the first half million $\left(500 * 10^{3}\right)$ of load cycles repeated loading was stopped and the load was released gradually to the minimum load, in increments. Deformations were recorded at every increment of unloading process.

A rest period of about six hours was chosen in to a count for the practical circumstances. The minimum load (1.4 ton) was kept applied to the tested beam during the rest period.

At the end of the first rest period, the deformations were recorded. Afterwards, the beam was loaded statically in increments up to $0.8 \mathrm{p}_{\text {us }}$ load where repeated loading with the same fatigue load function was 
applied for another half million $\left(500 * 10^{3}\right)$ of load cycles. The deformations and crack propagation were recorded in a manner similar to that adopted during first half million $\left(500 * 10^{3}\right)$-load cycle. The minimum load (1.4 ton) was maintained applied to the tested beam during a second period of six hours.

Repeated loading tests were continued up to failure in a manner similar to that described above. The time taken by each tested beam was different depending upon the ratio of tension steel reinforcement, and its type .The total duration of loading up to failure was different, depending upon the characteristics of the tested beams.

The beams deflections were measured, using dial gauge at mid-span. Dial gauges were used to measure the anchorage slips of longitudinal reinforcement in tension zone and vertical wires in the shear span. Strains at mid-depth of the stirrups were measured by strain gauge. Strains in concrete and longitudinal steel were measured by means of strain gauge at the positions shown in Figs. (1 and 2).

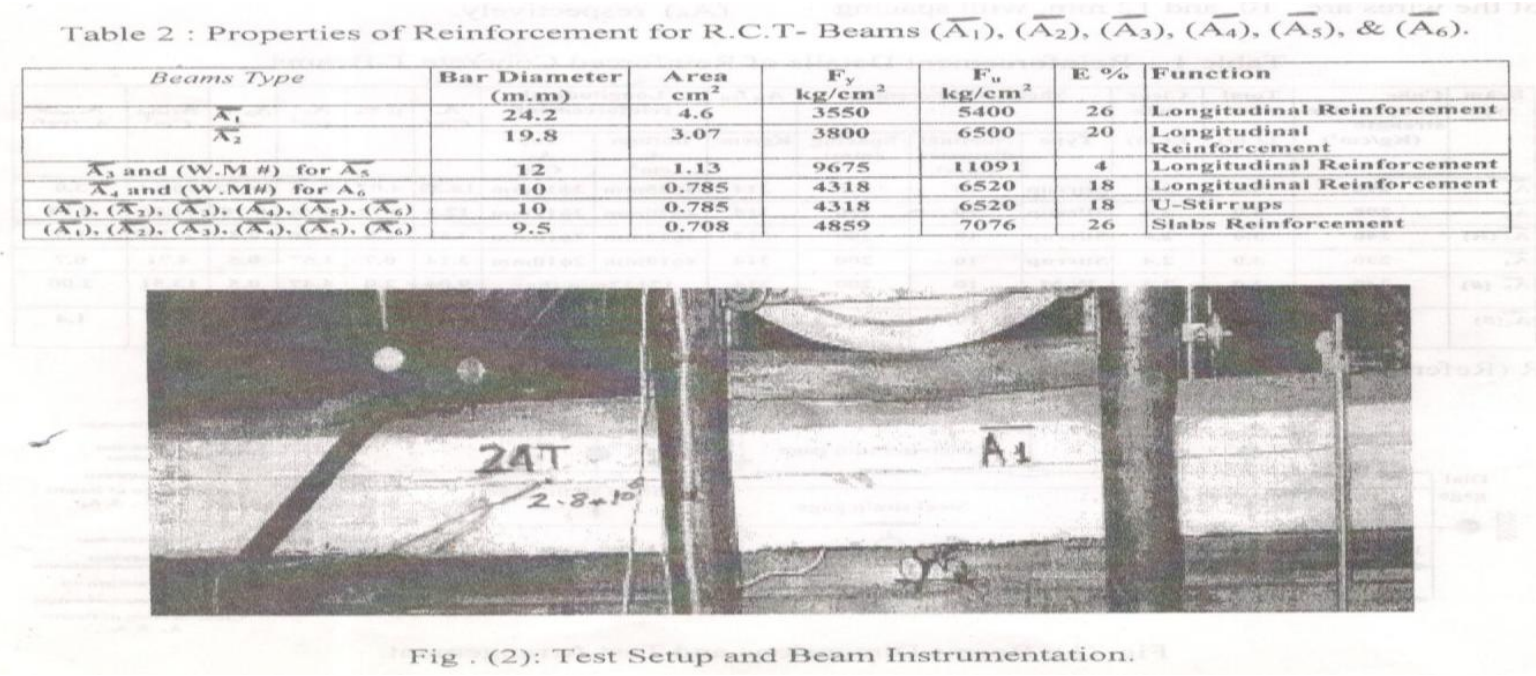

\section{Results And Discussions}

The results of SIX full-size T-beams were recorded. Four of them reinforced by longitudinal deformed bars welded with bent-up deformed wire U- stirrups are reported. Also the results of another two beams reinforced by deformed welded bars as well as mesh reinforcement are also reported. The major parameters of the study were the percentage of steel reinforcement in tension zone or its distribution all over the beam web, and behavior of this beams under repeated loading.

\section{4-1 Crack pattern:}

Cracking patterns of the beams are shown in Fig. (3). For all beams, cracks were initiated within the middle third of the beams with flexural type. As the load was increased the cracks were initiated within the mid height of shear span and grow downward and upward forming diagonal tension crack.

Generally the initiation and pattern of crack, in the first static load cycle (static loading reached $(0.8$ pus) somewhat similar to these occurred in the identical beams tested under static loading which mentioned in ref (13).

Additional diagonal cracks were then formed in the shear span zones under the repeated loading had level of ( 0.8 pus) with increasing of cycling load, several secondary cracks were observed and the diagonal cracks continued to grow excessively wide at expense of the others, which eventually led to final mode of failure(shear-comp.)beyond more than one million cycle of the beams $\left(\overline{\mathrm{A}}_{1}, \overline{\mathrm{A}}_{3(\mathrm{R})}, \overline{\mathrm{A}}_{5} \#\right)$. . For beam $\overline{\mathrm{A}}_{1}(\mu=4.07$ $\%$ ), failed at 2.8 million cycles .For beam $\bar{A}_{5} \#$ ( W.M.\# $12 / 10 \mu=2 \%$ ) failed at 1.71 million cycle . And not failed until to 2.0 million cycle for Ref. beam $\overline{\mathrm{A}}_{3(\mathrm{R})},(\mu=1.5 \%)$ but continuo to loading until failed under static loading with the same mode of failure.

But for beams $\left(\overline{\mathrm{A}}_{2}, \overline{\mathrm{A}}_{4}\right.$, and $\left.\overline{\mathrm{A}}_{6} \#\right)$ was failed by Flex. Compression mode of failure. The flexural cracks in the middle third of the beam length wide at expense of the others, which lies in the shear-span zones.

The modes of failure for tested beams are affected by the percentage of steel reinforcement $(\mu \%)$, welded mesh (W.M.\#), reinforcement and number of load cycle resulting repeated loads.

For beam $\bar{A}_{1, \text { although the }}$ using of high percentage of steel reinforcement $(4 \phi 25 \mathrm{~mm} ; \mu=4.07 \%)$, the beam failed under 2.8 million cycle and the mode of failure was shear-comp. But for beam $\overline{\mathrm{A}}_{2}$ with moderate percentage of steel reinforcement $(4 \phi 20 \mathrm{~mm} ; \mu=2.72 \%)$, the beam not failed until 3 million cycle and the mode 
of failure was flex. Comp. after continued by static loading. This indicated that the using of moderate percentage of steel reinforcement $(2 \%<\mu<4 \%)$ in beam $\overline{\mathrm{A}}_{2}$ affecting the mode of failure.

Beam $\left(\overline{\mathrm{A}}_{5} \#\right)$ failed by shear-comp. under repeated loading at 1.71 million cycle although the percentage of reinforcement by using welded mesh (W.M.\#) reinforcement ( \# 12/10, $\mu=2 \%$ ), is small if it is comparing by the percentage reinforcement $(\mu=4.07 \%)$, using in beam $\left(\overline{\mathrm{A}}_{1}\right)$.

Mode of failure for beam $\left(\overline{\mathrm{A}}_{6} \#\right)$ tested under repeated loading was flex-comp.at 0.3 million cycle only and this attributed to the low percentage of reinforcement $(\mu=1.4 \%)$, by resulting the used of welded mesh (W.M.\#), had a small diameter $(10 \mathrm{~mm})$, in both longitudinal and vertical direction of the beam.

Deformed welded mesh (W.M.\#), significantly improves the control of cracking and mode of failure than an equivalent amount of main steel reinforcement. However, the using of high \%percentage of steel resulting from higher bar diameter did not improve the flexural and shear cracking capacity of R.C. beams.

The smaller crack indicates the improved bond performance of the smaller deformed diameter (W.M.\#), which led to a larger number of smaller cracks. However the beams reinforced by main longitudinal steel eventually developed larger cracks than they, are reinforced by (W.M.\#).

These crack patterns indicate that the (W.M.\#), reinforcement was capable of redistribution the stresses in the shear span without preventing the brittle mode of failure. Welded mesh (W.M.\#), reinforcement further improves the performance of an anchoring and augments crack control.

Generally the repeated loading increases both number and width of the formed cracks and its does not influence significantly nither the pattern of crack nor the mode of failure.

Also generally the repeated loading tends to increase the numbers of secondary cracks however it has no effect up the final mode of failure in comparison with that occurred under static loading (ref . 13 ).

The modes of failure for tested beams are shown in Fig.(3).

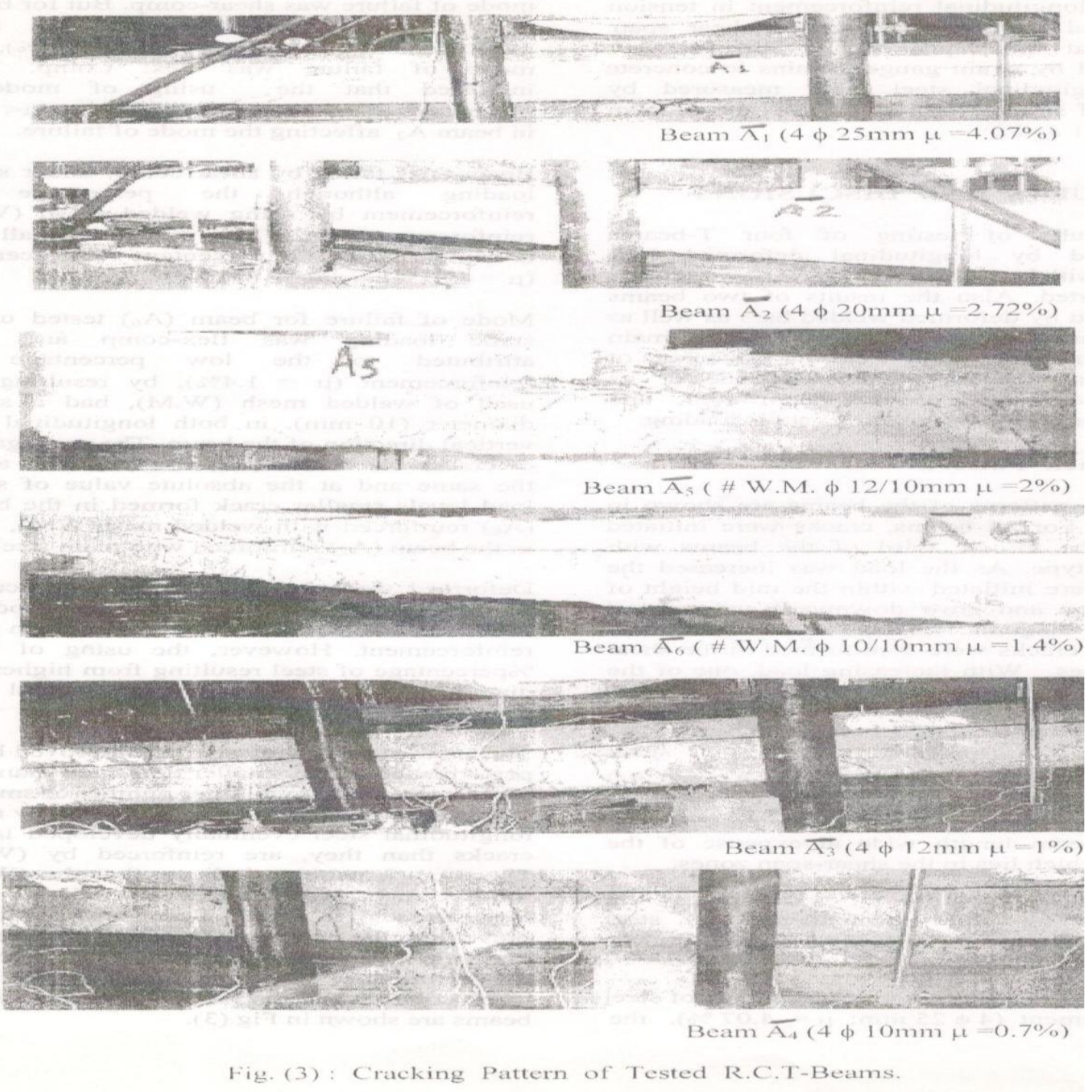




\section{4-2 Induced Deformations}

\section{4-2-1 Load- Deflection.}

The deflection is a function not only of the beam span, loading type i.e. the position of the load points but also of steel arrangement, and point of measuring. This would affect the ultimate capacity of a beam. Fig $(4,5,6,7,8,9,10 \& 11)$ shows plots of central deflection versus the applied load from zero loading up to failure for all tested beams.

Fig. (4 to11) shows the relationship between the measured max. deflection at mid -span of beams relative to the percentage of longitudinal steel reinforcement ( $\square \%$ ) at every stages of loading from first flexural crack load (Pcr) until80\% of static failure load (0.8PUs)and also measured every $(250 * 103)$ of load cycles and at half million $(500 * 103)$ of load cycles repeated loading until the failure load (Pu.). The relation summarized the effect of percentage of longitudinal reinforcement which effect in tension zone or distribution along the beam web as horizontal bars to made welded mesh (W.M.\#), reinforcement type. From this relation the using of welded mesh reinforcement enhancement the beam capacity for deflection at every stages of loading.

These figs. (4) to. (11), emphasize that the repeated loading always increases the induced maximum defection of the beams for the tested beams, The recorded defection at the end of loading by one million cycles ranged between $89 \%$ to $148 \%$ of the corresponding deflection refereeing to the references beam $\bar{A} 3(\mathrm{R})$. The $\%$ decreases and increases is mainly depending on the percentage of main steel reinforcing and its arrangement (mesh reinforcement\#).

The ultimate values of the deflection at failure for the tested beams under repeated loading are given in table (3) together with the corresponding values of influential beams tested under static loading (ref.13). For tested beams the maximum defection obtained under repeated loading is higher than the corresponding value obtained under static loading Pus. Regardless the values of $\mu \%$ and the mode of beam failure.

For beam having ( $\mu=4.07 \%$ )failed in shear-comp, The maximum defection at failure of fatigued beams is only about $34.7 \%$ more than the corresponding static values.

A comparison of the results were tabulated in table (3) which indicate that :-

At cracking stage, the load-deflection characteristics of all beams were nearly similar. The beams behaved in elastic stage up to about 25 percent of the ultimate load.

1- For all tested beams from the load-deflection diagrams it is obvious that the diagram broken at every stages of cracking, initial flexural crack (at cracking load $\mathrm{p}_{\mathrm{cr}}$ ), diagonal shear crack in shear zone (at shear crack load $\mathrm{Q}_{\mathrm{cr}}$ ), before final crack (at $0.8 \mathrm{P}_{\mathrm{us}}$ ), failure crack (flexural-comp. or shear - comp.) at failure load $\mathrm{P}_{\mathrm{u}}$.

2- Beyond the cracking load there was a significant difference between results of load-deflection for all tested beams.

a- The values of max. deflection of beams $\left(\bar{A}_{1}\right)$ and $\left(\bar{A}_{2}\right)$ are lower than the results for beam $\overline{\mathrm{A}}_{3(\mathrm{R})}$ (Reference beam).

b- The max. deflection for beam $\left(\overline{\mathrm{A}}_{4}\right)$ are to be the same values for beam $\overline{\mathrm{A}}_{3(\mathrm{R})}$ (Reference beam).

c- But the max. deflection values for beam $\bar{A}_{5} \#\left(\right.$ W.M.\#12/10) and beam $\bar{A}_{6} \#$ (W.M.\#10/10) is to be more than values for beams $\bar{A}_{3(\mathrm{R})}$ (Reference beam).

3- Using of welded mesh (W.M.\#) reinforcement enhancement the ability of the beams to be deflected more than other beams reinforced by main steel in tension zone. This attributed to the sing of welded mesh (W.M.\#) reinforcement increasing the ductility of beams.

Figs. (5-10) show the effect of different parameters on the deflection values all over the beams span. Generally, as the load was applied, deflection values increases gradually from support to the center of beam (point of max. deflection). When the applied load increases the deflection all over the beam span increases and its increments of increasing depending upon the different beam models. The increase of main steel reinforcement decreases the deflection values as shown in Figs. (5-10).

Increasing the area of horizontal web reinforcement of the beam affected the deflection values of the beam as shown in figs. $(9 \& 10)$. Beams with higher ratio of horizontal web reinforcement showed more ductile behaviour than that with smaller ratio.

Mid-span deflections at first cracking load were independent not only by the \% percentage reinforcement but also by horizontal web reinforcement. Formation of the first diagonal crack significantly reduced the beam stiffness. Only the beam reinforced by welded mesh (W.M\#), exhibited same ductility at failure. The degree of ductility is depending upon the amount of horizontal web reinforcement.

Figs. ( 5, 6,7,8 \& 10)show that the deflection in side of the roller support is more pronounced than occurred near the hinged support and this means that the hinged support only permitted the beam to rotation and restrict the beam to deflect until the load value $\left(0.8 \mathrm{P}_{\mathrm{Us}}\right)$, and this phenomena is vanished when the measuring 
deflection becomes in the mid - span. But the roller supports that permit beams to movement and this increase the measured deflection near the support.

From fig. (9) The differences in deflection values near the two supports were diminish and the distribution of deflection smooth until failure load for beam with heavy welded mesh reinforcement (W.M. $\# 12 / 10)$.

Table (3):- Induced Deflection Deformations of Tested Beams.

\begin{tabular}{|c|c|c|c|c|c|c|c|c|c|c|c|c|c|c|c|}
\hline $\begin{array}{c}\text { Bea } \\
\text { m } \\
\text { type }\end{array}$ & $\begin{array}{c}\delta \\
(\mathrm{mm}) \\
\text { at } \\
\mathrm{P}_{\mathrm{cr}}\end{array}$ & $\begin{array}{c}\delta \\
(\mathrm{mm}) \\
\text { at } \\
\mathrm{Q}_{\mathrm{cr}}\end{array}$ & $\begin{array}{c}\delta \\
(\mathrm{mm}) \\
\text { at } 0.8 \\
\mathrm{P}_{\mathrm{us}}\end{array}$ & $\begin{array}{c}\delta \\
(\mathrm{mm}) \\
\text { at } \mathrm{P}_{\mathrm{us}} \\
\text { (REF. 13) }\end{array}$ & $\begin{array}{c}\delta \\
(\mathrm{mm}) \\
\text { at } 0.8 \\
\mathrm{P}_{\mathrm{us}} \& \\
0.3^{*} \\
10^{6} \\
\text { cycle }\end{array}$ & $\begin{array}{c}\delta \\
(\mathrm{mm}) \\
\text { at } 0.8 \\
\mathrm{P}_{\text {us }} \& \\
0.5^{*} \\
10^{6} \\
\text { cycle } \\
\end{array}$ & $\begin{array}{c}\delta \\
(\mathrm{mm}) \\
\text { at } 0.8 \\
\mathrm{P}_{\text {us }} \& \\
1.0^{*} \\
10^{6} \\
\text { cycle }\end{array}$ & $\begin{array}{c}\delta \\
(\mathrm{mm}) \\
\text { at } 0.8 \\
\mathrm{P}_{\text {us }} \& \\
1.5^{*} \\
10^{6} \\
\text { cycle }\end{array}$ & $\begin{array}{c}\delta \\
(\mathrm{mm}) \\
\text { at } 0.8 \\
\mathrm{P}_{\mathrm{us}} \& \\
1.7^{*} \\
10^{6} \\
\text { cycle }\end{array}$ & $\begin{array}{c}\delta \\
(\mathrm{mm}) \\
\text { at } 0.8 \\
\mathrm{P}_{\text {us }} \& \\
2.0^{*} \\
10^{6} \\
\text { cycle }\end{array}$ & $\begin{array}{c}\delta \\
(\mathrm{mm}) \\
\text { at } 0.8 \\
\mathrm{P}_{\text {us }} \& \\
2.5^{*} \\
10^{6} \\
\text { cycle }\end{array}$ & $\begin{array}{c}\delta \\
(\mathrm{mm}) \\
\text { at } 0.8 \\
\mathrm{P}_{\mathrm{us}} \& \\
2.8^{*} \\
10^{6} \\
\text { cycle }\end{array}$ & $\begin{array}{c}\delta(\mathrm{mm}) \\
\text { at } 0.8 \mathrm{P}_{\mathrm{us}} \\
\& 3.0^{*} \\
10^{6} \text { cycle }\end{array}$ & $\begin{array}{c}\delta(\mathrm{mm}) \\
\text { at } P_{\text {us }}\end{array}$ & $\begin{array}{l}\text { Mode of } \\
\text { Failure }\end{array}$ \\
\hline$\overline{\mathrm{A}}_{1}$ & 2.0 & 3.3 & 7.6 & 11.5 & 9.05 & 9.4 & 9.75 & 10.125 & 10.55 & 10.75 & 11.05 & $\begin{array}{c}11.5 \\
\text { Failure } \\
24 \text { ton( } \\
\text { D) }\end{array}$ & - & - & $\begin{array}{c}\text { Bond } \\
\text { Shear- } \\
\text { Comp. } \\
\text { Failure (D) }\end{array}$ \\
\hline$\overline{\mathrm{A}}_{2}$ & 2.0 & 4.0 & 8.0 & 12 & 9.375 & 9.55 & 9.95 & 10.3 & 10.375 & 10.55 & 11.00 & 11.5 & 12.05 & $\begin{array}{c}15.375 \\
\text { Failure } \\
28 \text { ton } \\
\text { static }\end{array}$ & $\begin{array}{c}\text { Flexural- } \\
\text {.Comp. } \\
\text { Failure (S) }\end{array}$ \\
\hline $\begin{array}{l}\overline{\mathrm{A}}_{3} \\
\text { (R) }\end{array}$ & 1.85 & 6.096 & 8.84 & 12.75 & 10.24 & 10.49 & 10.97 & 11.25 & 11.95 & 12.85 & - & - & - & $\begin{array}{c}15.5 \\
\text { Failure } \\
16 \text { ton } \\
\text { static }\end{array}$ & $\begin{array}{c}\text { Shear- } \\
\text { Comp. } \\
\text { Failure (S) }\end{array}$ \\
\hline$\overline{\mathrm{A}}_{4}$ & 2.85 & 9.96 & 9.96 & 12.85 & 13.56 & 14.8 & 15.83 & 15.95 & $\begin{array}{c}16.09 \\
\text { Failure } \\
8 \\
\text { ton(D) }\end{array}$ & - & - & - & - & - & $\begin{array}{c}\text { Flexural- } \\
\text { Comp. } \\
\text { Failure (D) }\end{array}$ \\
\hline$\overline{\mathrm{A}}_{5} \#$ & 1.95 & 5.6 & 10.5 & 15.5 & 14.475 & 14.1 & 16.25 & 20.15 & $\begin{array}{c}20.15 \\
\text { Failure } \\
19.2 \text { to } \\
\mathrm{n}(\mathrm{D})\end{array}$ & - & - & - & - & - & $\begin{array}{c}\text { Shear- } \\
\text { Comp. } \\
\text { Failure (D) }\end{array}$ \\
\hline$\overline{\mathrm{A}}_{6} \#$ & 2.25 & 7.5 & 14.9 & 15.5 & $\begin{array}{c}20.3 \\
\text { Failure } \\
13.5 \\
\text { ton(D) }\end{array}$ & - & - & - & - & - & - & - & - & - & $\begin{array}{c}\text { Flexural - } \\
\text { Comp..Fai } \\
\text { ure (D) }\end{array}$ \\
\hline
\end{tabular}

(R)-Reference Beam

(W.M. \#) Mesh Reinforcement (S) Static Failure.

D) Dynamic Failure.

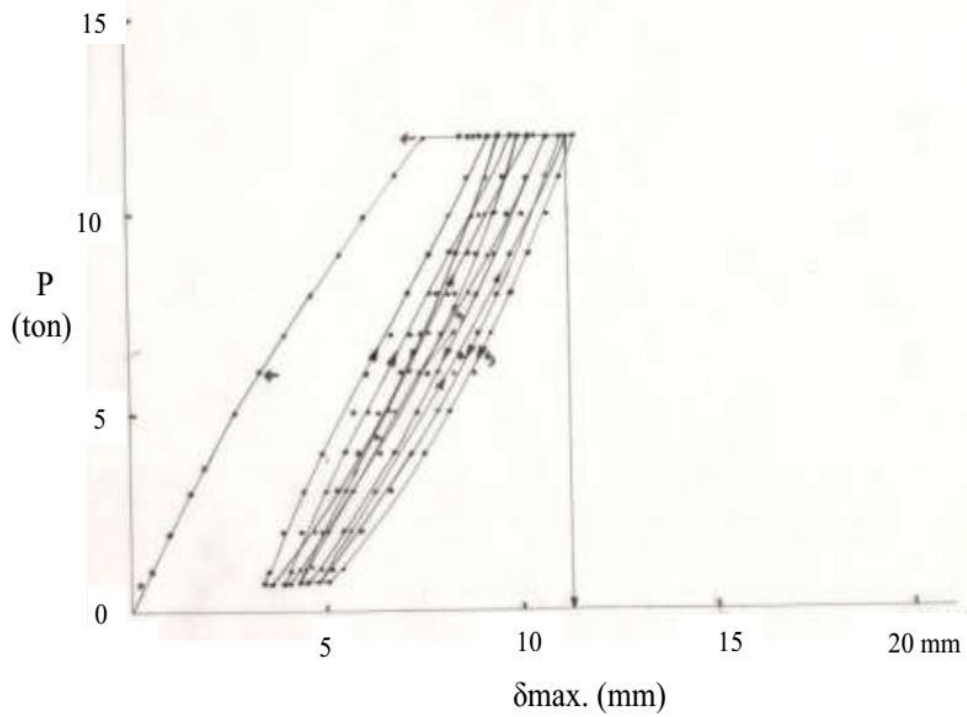

Fig.(4-1) Load-deflection relationship for Beam $\overline{\mathrm{A}} 1$. 


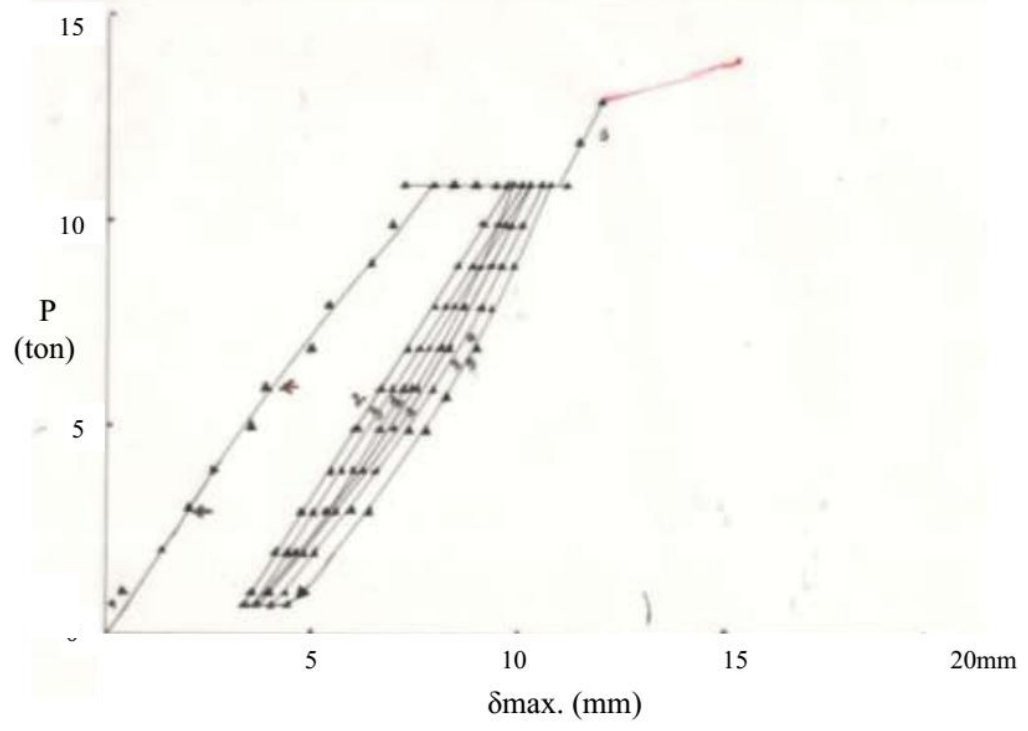

Fig.(4-2) Load-deflection relationship for Beam $\overline{\mathrm{A} 2}$.

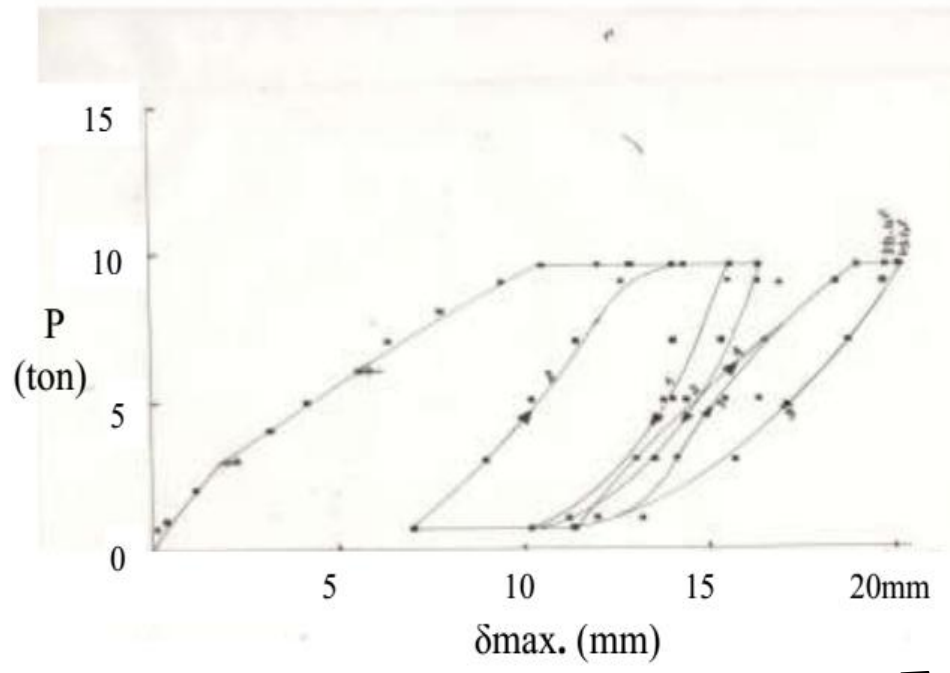

Fig.(4-3) Load-deflection relationship for Beam $\overline{\mathrm{A5}} \#$.

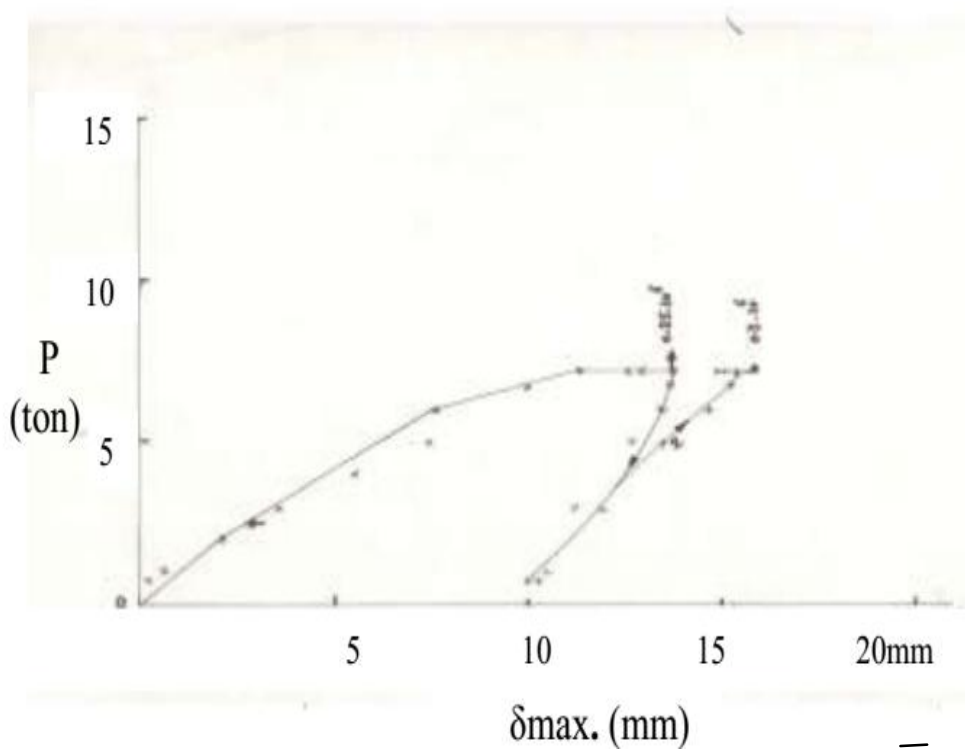

Fig.(4-4) Load-deflection relationship for Beam $\overline{\mathrm{A}} \overline{\#}$. 


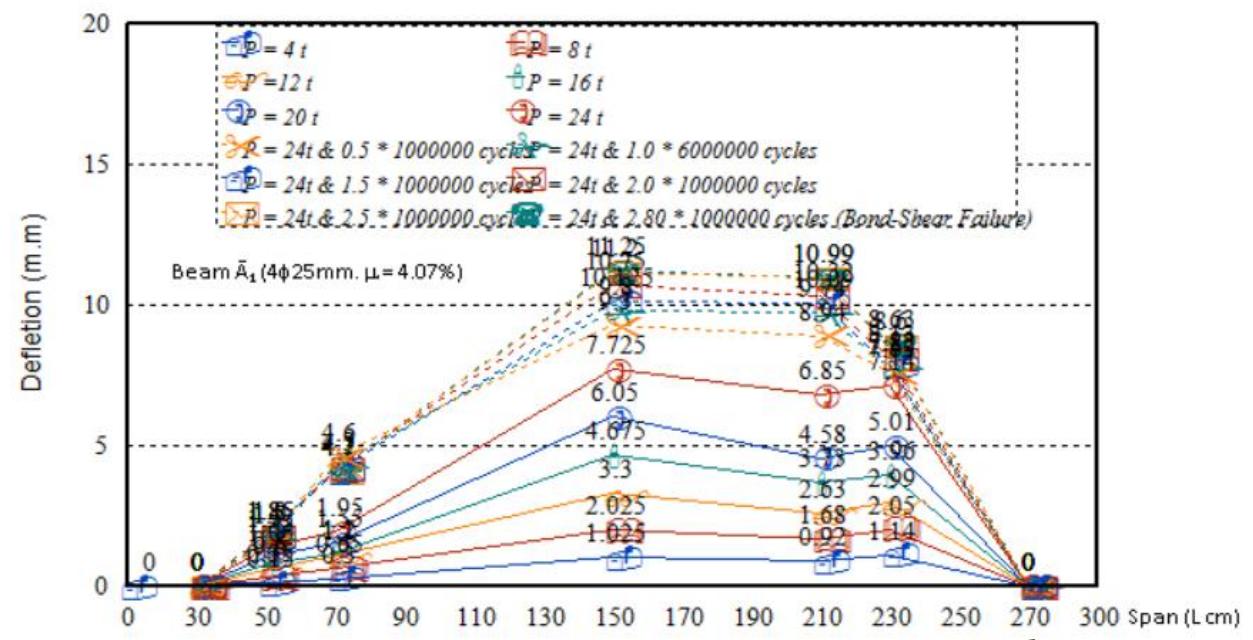

Fig.(5) Load deflection-span relationship for beam (A $\overline{1})$

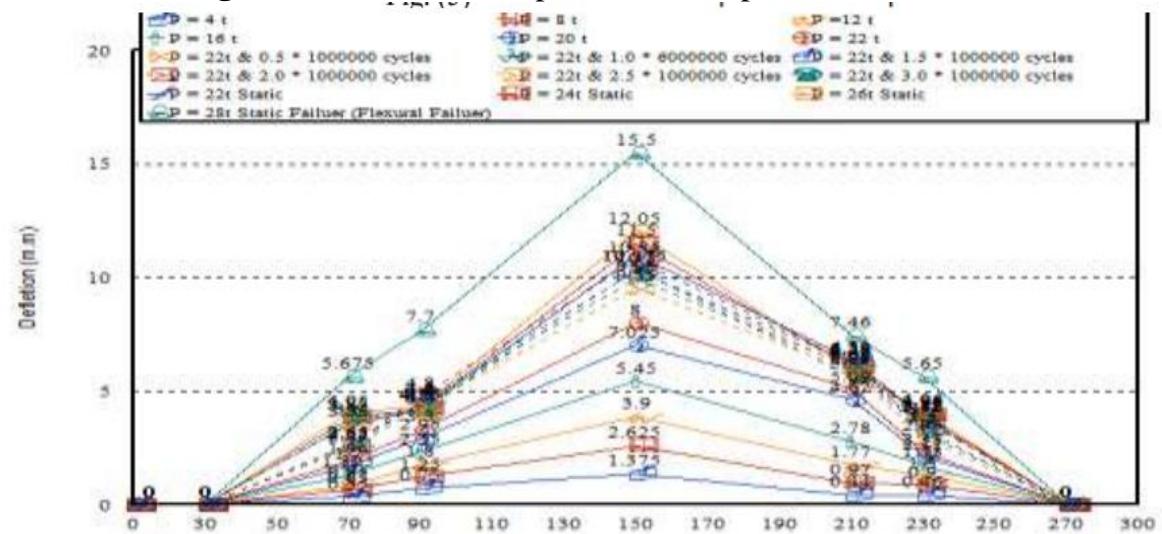

Fig.(6) Load deflection-span relationship for beam (A $\overline{2})$

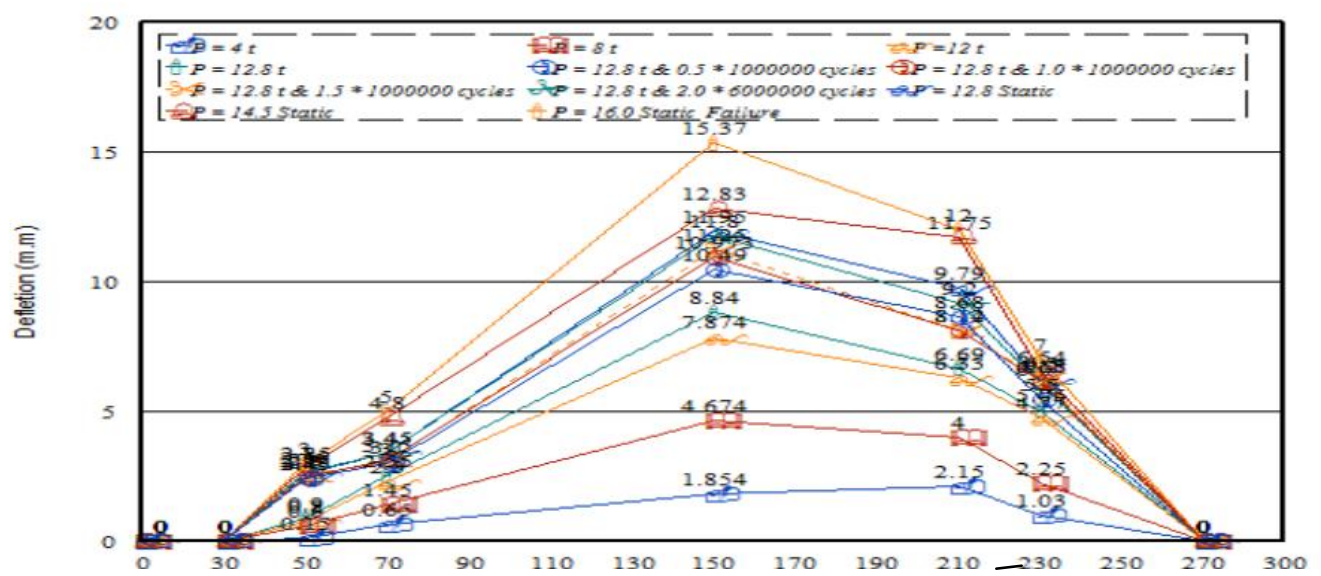

Fig.(7) Load deflection-span relationship for beam (A). 


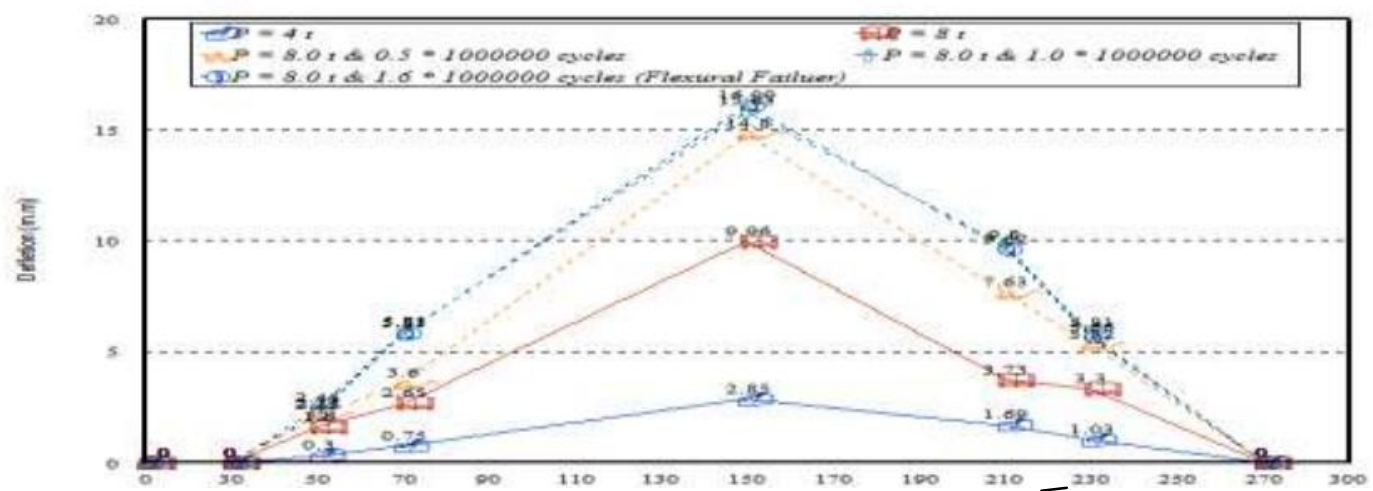

Fig.(8) Load deflection-span relationship for beam ( $\overline{\mathrm{A}} 4)$.

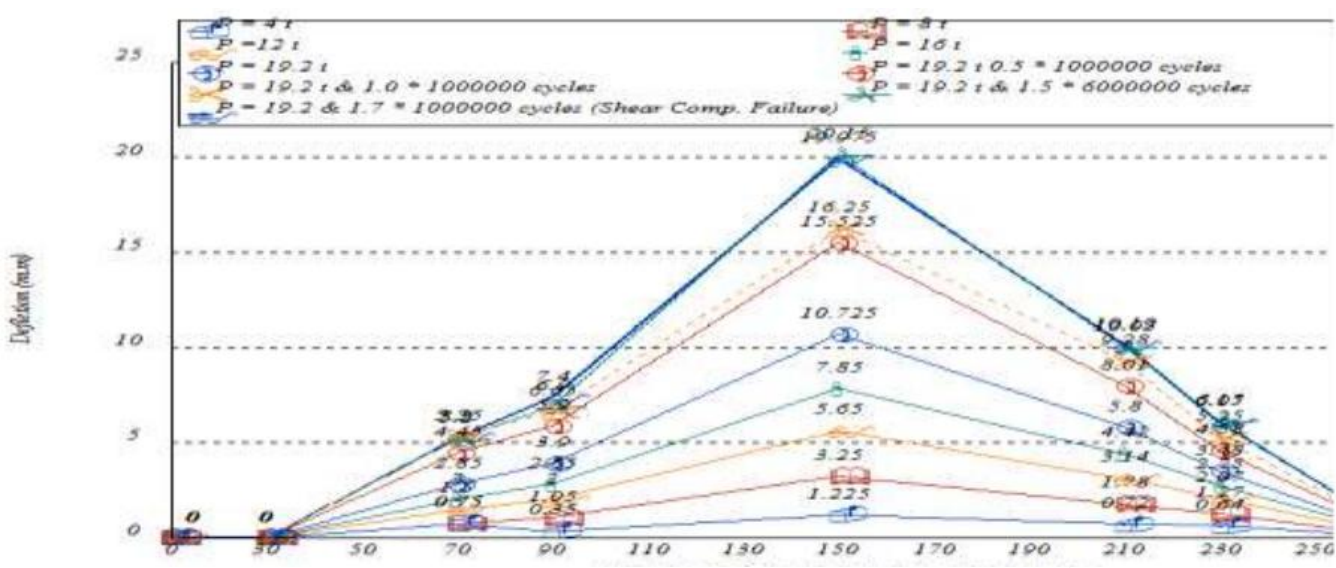

Fig.(9) Load deflection-span relationship for beam (A5).

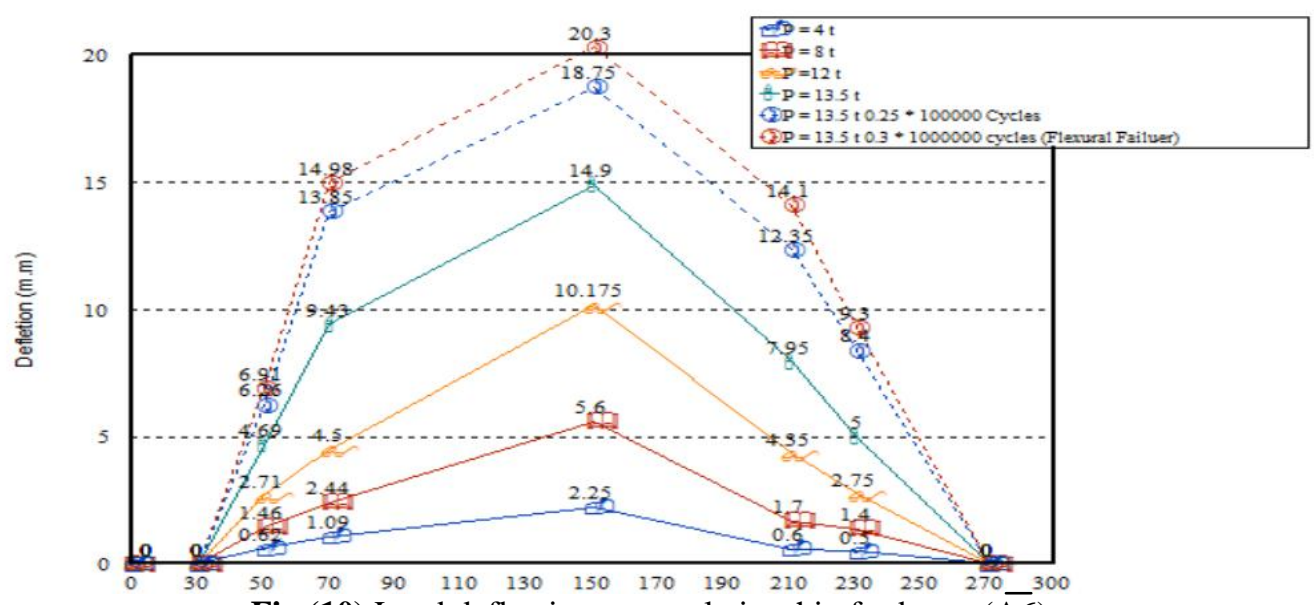

Fig.(10) Load deflection-span relationship for beam (A6). 


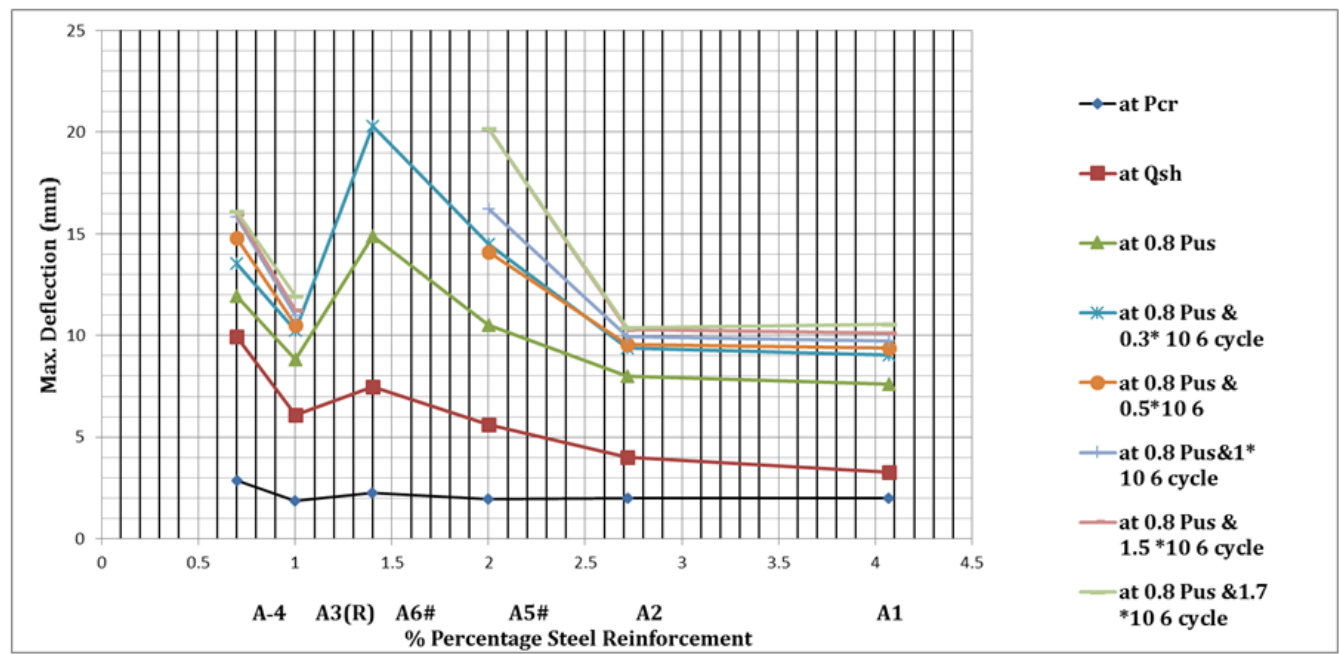

Fig.(11) Max.Deflection-\% Percentage Steel Reinforcement relationship.

\section{4-2-2-Load-slip Relationship :}

Figs. (12 \&13). shows the relationship between the total applied load and the measured slip at two sides of beams (at hinged support and at roller support). The measured slip at level of tension steel reinforcement for all tested beams. The relationship indicated that broken lines represented every stages of loading at first cracking load $\left(\mathrm{P}_{\mathrm{cr}}\right)$ and at shear crack load $\left(\mathrm{Q}_{\mathrm{cr}}\right)$ and at $\left(0.8 \mathrm{P}_{\mathrm{us}}\right)$ and also measured every $\left(250^{*} 10^{3}\right)$ of load cycles and at half million $\left(500 * 10^{3}\right)$ of load cycles repeated loading until the failure load $\left(\mathrm{P}_{\mathrm{u}}\right)$. Also, it indicated that the values at hinged support were littler than at roller support. The values of slip at two ends of beam showing that the increases of longitudinal reinforcement percentage decrease the values of slip. This means that the slip of steel bars is a function of shear cracking load and beam stiffness. Also the length of anchorage length is to be enough for all beams..

AT the support zones in the beams, the used welded transverse wires interrupt the free transfer of stresses from steel to concrete. It may be assumed that these welded transverse wires act as rigid joints that do not allow movement of steel relative to concrete and localized deformation. Hence, any local crushing of the concrete at points of intersection of the main and transverse wires is ignored.

Figs. (12-1) to (12-4) summarized the results of slips at hinged support and at roller support respectively for all tested beams. The analysis of results showed that the slip for steel reinforcement is increased by decreasing \% percentage of steel reinforcement. This attributed to the bond action between steel reinforcement and concrete is more enough for over and balanced reinforced section $(\mu>2 \%)$ rather than under reinforced section $(\mu<2 \%)$.

The type of support affecting the measuring slip. The slip values at roller support are nearly 4 times values of slip at hinged support. Also the hinged support restricts the relative motion of steel bars from the surrounding concrete. 


\begin{tabular}{|c|c|c|c|c|c|c|c|c|c|c|c|c|c|c|c|}
\hline $\begin{array}{c}\text { Bea } \\
\text { m } \\
\text { type }\end{array}$ & $\begin{array}{c}\text { Slip } \\
(\mathrm{mm}) \\
\text { at } \\
\mathrm{P}_{\mathrm{cr}}\end{array}$ & $\begin{array}{c}\text { Slip } \\
(\mathrm{mm}) \\
\text { at } \\
\mathrm{Q}_{\alpha}\end{array}$ & $\begin{array}{c}\text { Slip } \\
(\mathrm{mm}) \\
\text { at } 0.8 \\
\mathrm{P}_{\mathrm{ws}}\end{array}$ & $\begin{array}{c}\text { Slip } \\
(\mathrm{mm}) \\
\text { at } 0.8 \\
\mathrm{P}_{\mathrm{wu}} \& \\
0.3^{*} \\
10^{6} \\
\text { cycle }\end{array}$ & $\begin{array}{c}\text { Slip } \\
(\mathrm{mm}) \\
\text { at } 0.8 \\
\mathrm{P}_{\mathrm{us}} \& \\
0.5^{*} \\
10^{6} \\
\text { cycle }\end{array}$ & $\begin{array}{c}\text { Slip } \\
(\mathrm{mm}) \\
\text { at } 0.8 \\
\mathrm{P}_{\mathrm{us}} \& \\
1.0^{*} \\
10^{6} \\
\text { cycle }\end{array}$ & $\begin{array}{c}\text { Slip } \\
(\mathrm{mm}) \\
\text { at } 0.8 \\
\mathrm{P}_{u s} \& \\
1.5^{*} \\
10^{6} \\
\text { cycle }\end{array}$ & $\begin{array}{c}\text { Slip } \\
(\mathrm{mm}) \\
\text { at } 0.8 \\
\mathrm{P}_{\mathrm{us}} \& \\
1.7^{*} \\
10^{6} \\
\text { cycle }\end{array}$ & $\begin{array}{c}\text { Slip } \\
(\mathrm{mm}) \\
\text { at } 0.8 \\
\mathrm{P}_{\mathrm{us}} \& \\
2.0^{*} \\
10^{6} \\
\text { cycle }\end{array}$ & $\begin{array}{c}\text { Slip } \\
(\mathrm{mm}) \\
\text { at } 0.8 \\
\mathrm{P}_{\mathrm{us}} \& \\
2.5^{*} \\
10^{6} \\
\text { cycle }\end{array}$ & $\begin{array}{c}\text { Slip } \\
(\mathrm{mm}) \\
\text { at } 0.8 \\
\mathrm{P}_{\mathrm{us}} \& \\
2.8^{*} \\
10^{6} \\
\text { cycle }\end{array}$ & $\begin{array}{c}\text { Slip } \\
(\mathrm{mm}) \text { at } \\
0.8 \mathrm{P}_{\mathrm{us}} \text { \& } \\
3.0^{*} 10^{6} \\
\text { cycle }\end{array}$ & $\begin{array}{l}\text { Slip } \\
(\mathrm{mm}) \\
\text { at } \mathrm{P}_{\mathrm{us}}\end{array}$ & $\begin{array}{r}\text { Mode of } \\
\text { Failure }\end{array}$ & $\begin{array}{c}\text { Slip (mm) } \\
\text { at } P_{\mathrm{Us}} \\
\text { (REF. 13) }\end{array}$ \\
\hline$\overline{\mathrm{A}}_{1}$ & 0.25 & 0.4 & 0.95 & 1.65 & 1.825 & 1.875 & 2.0 & & & & $\begin{array}{l}\text { Failure } \\
\text { at } 24 \\
\text { ton(D) }\end{array}$ & - & - & $\begin{array}{l}\text { Bond Shear- } \\
\text { Comp. } \\
\text { Failure (D) }\end{array}$ & 0.93 \\
\hline$\overline{\mathrm{A}}_{2}$ & 0.225 & 1.075 & 1.275 & 1.65 & 1.65 & 1.8 & 2.6 & & & & & & $\begin{array}{c}\text { Failure } \\
\text { at } 28 \\
\text { ton } \\
\text { static }\end{array}$ & $\begin{array}{l}\text { Flexural- } \\
\text { Comp. } \\
\text { Failure (S) }\end{array}$ & 1.6 \\
\hline $\bar{A}_{3(\mathrm{R})}$ & 0.305 & 1.02 & 1.45 & 1.93 & 1.98 & 2.32 & 2.8 & & & - & - & - & $\begin{array}{c}\text { Failure } \\
\text { at } 16 \\
\text { ton } \\
\text { static }\end{array}$ & $\begin{array}{c}\text { Shear- } \\
\text { Comp. } \\
\text { Failure (S) }\end{array}$ & 1.86 \\
\hline$\overline{\mathrm{A}}_{4}$ & 0.4 & 1.4 & 1.7 & 7.26 & 7.395 & 8.79 & 9.5 & $\begin{array}{l}\text { Failure } \\
\text { at } 8 \\
\text { ton(D) }\end{array}$ & - & - & - & - & - & $\begin{array}{c}\text { Flexural- } \\
\text { Comp. } \\
\text { Failure (D) }\end{array}$ & 1.8 \\
\hline$\overline{\mathrm{A}}_{5} \#$ & 0.2 & 0.6 & 1.4 & 2.3 & 2.525 & 2.75 & 2.95 & $\begin{array}{l}\text { Failure } \\
\text { at } 19.2 \\
\text { ton(D) }\end{array}$ & - & - & - & - & - & $\begin{array}{c}\text { Shear- } \\
\text { Comp. } \\
\text { Failure (D) }\end{array}$ & 1.67 \\
\hline$\overline{\mathrm{A}}_{6} \#$ & 0.25 & 0.85 & 1.6 & $\begin{array}{l}6.825 \\
\text { Failure } \\
\text { at } 13.5 \\
\text { ton(D) }\end{array}$ & - & - & - & - & - & - & - & - & - & $\begin{array}{l}\text { Flexural - } \\
\text { Comp.Failu } \\
\text { re (D) }\end{array}$ & 1.7 \\
\hline
\end{tabular}
(R)-Reference Beam
(W.M. \#) Mesh Reinforcement
$\begin{array}{lll}\text { (S) Static Fail } \quad \text { (D) Dynamic Failure. } & \end{array}$

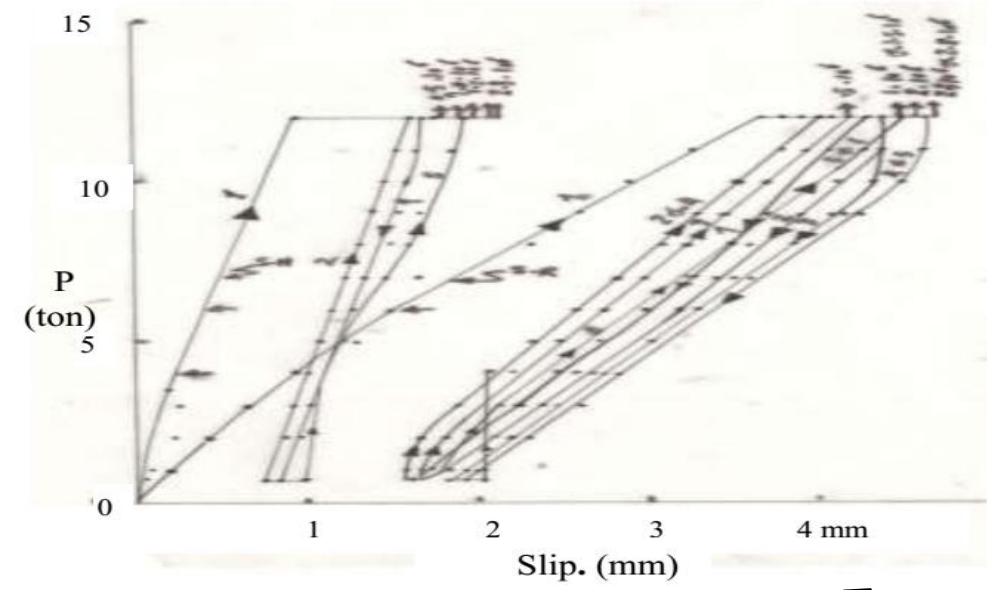

Fig.(12-1) Load-slip relationship for Beam $\overline{\mathrm{A}}$.

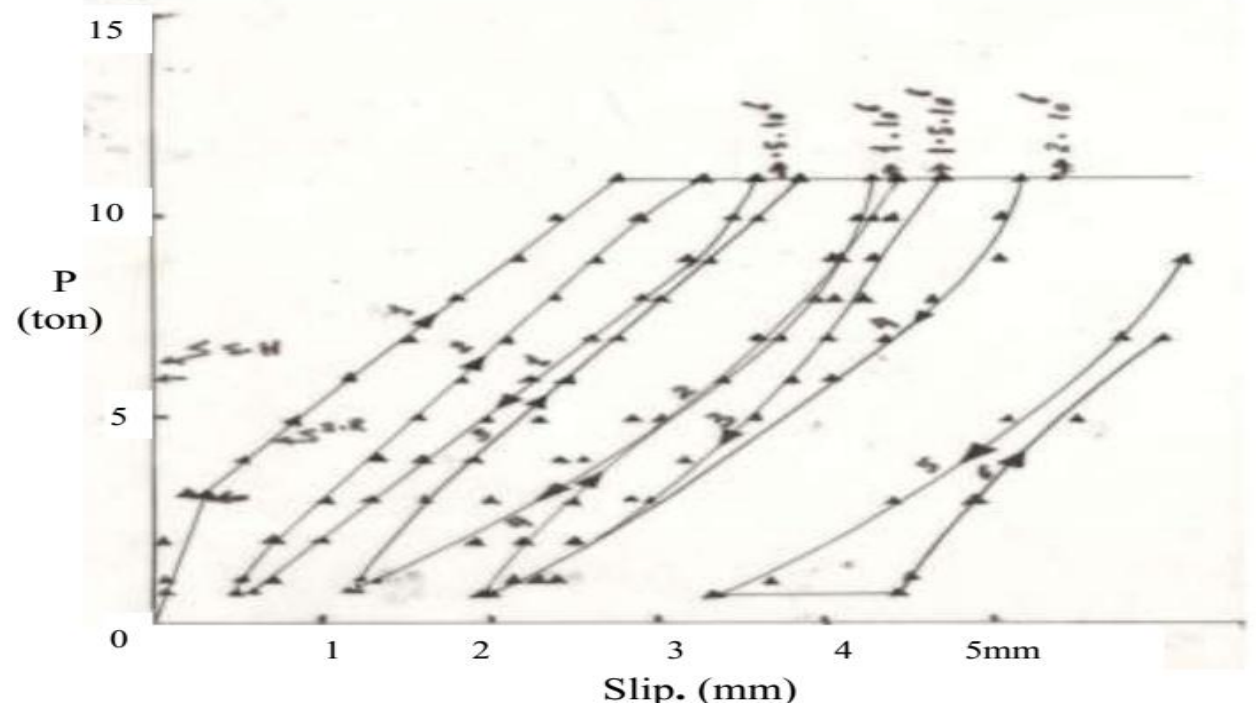

Fig.(12-2) Load-slip relationship for Beam $\overline{\mathrm{A} 3}$ 


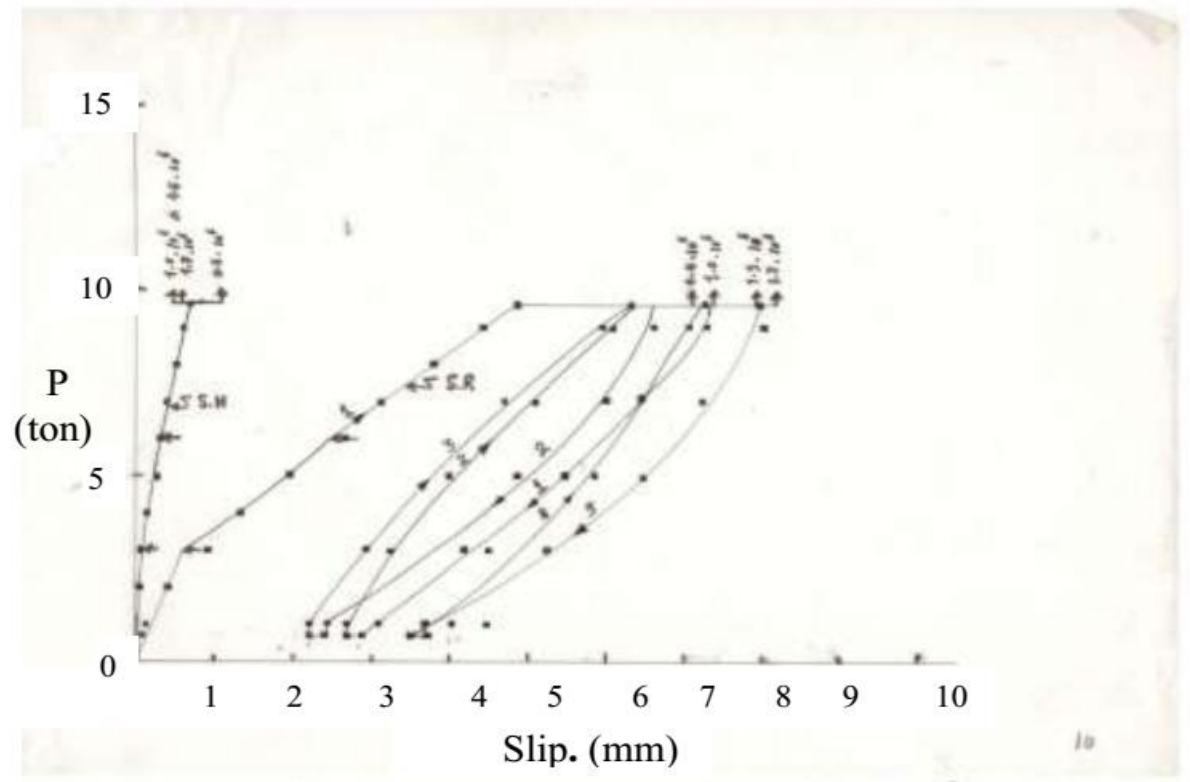

Fig.(12-3) Load-slip relationship for Beam A $\overline{5 \#}$

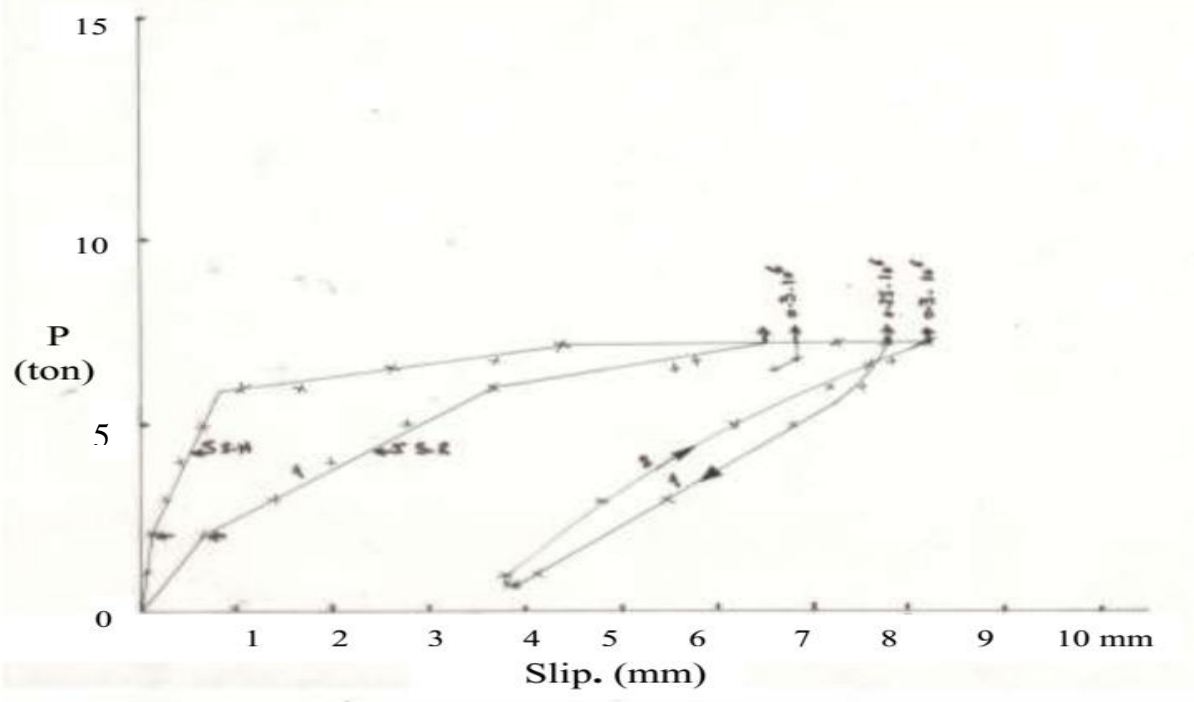

Fig.(12-4) Load-slip relationship for Beam $\overline{\mathrm{A}} \#$

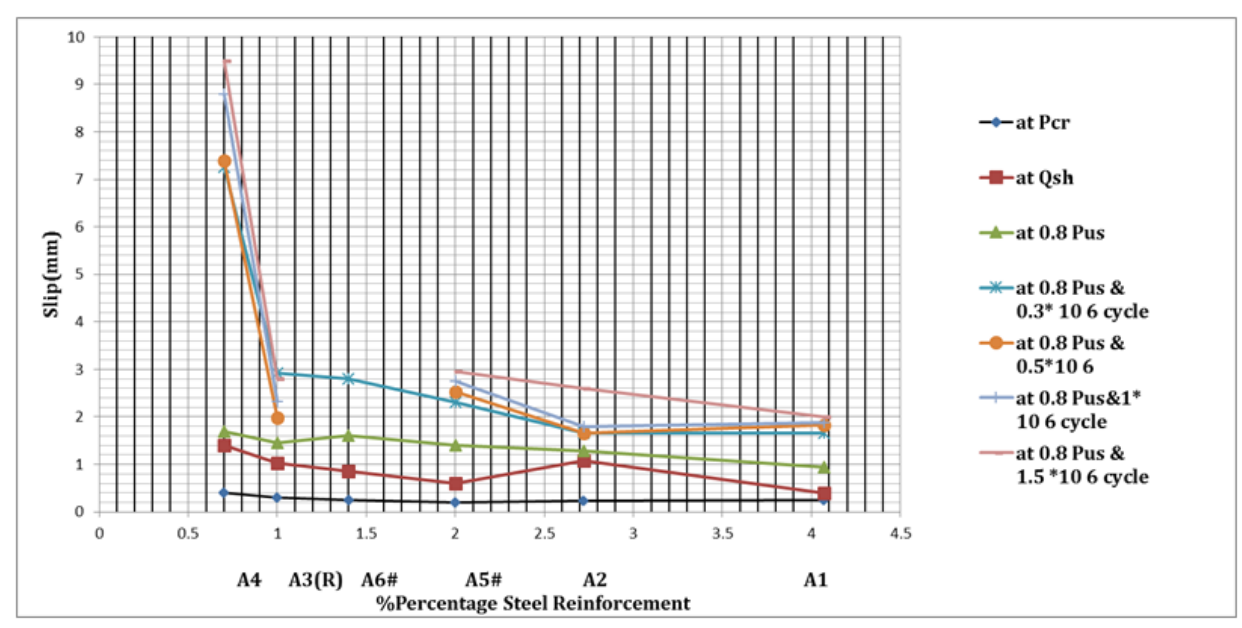

Fig.(13) Slip- \% Percentage Steel Reinforcement relationship. 


\section{4-2-3-Load-Strains Relations:}

\section{4-2-3-1-Stirrups Strain ((zstir)}

From fig. (14), the stirrups strain values verses $\mu \%$ indicated that the stirrups strain values fluctuated not only according to the \% of steel amount but also according to the modes of failure. The stirrups strain for beams having (shear-comp.), mode of failure is higher than that for beams having (flex.-comp.), mode of failure regardless the type of beam reinforcement.

For beams having (shear- comp.), mode of failure in the shear span the stirrups near the support exhibit higher strains; i.e. contribute more to the load- carrying capacity than the stirrup near the point of load. Since during the initial stages of loading the region of the diagonal tension cracking is closer to the bottom fiber near the support, the stirrups near the supports are more effective. The stirrup near the point load becomes effective when the crack is to propagate into the load point at the ultimate load stage reached.

The strains in the stirrups will be higher when a diagonal crack crosses them, because the diagonal crack can be considered as yield line. The stirrup strain information can be used as an indicator of the degree of contribution of stirrup reinforcement as these locations.

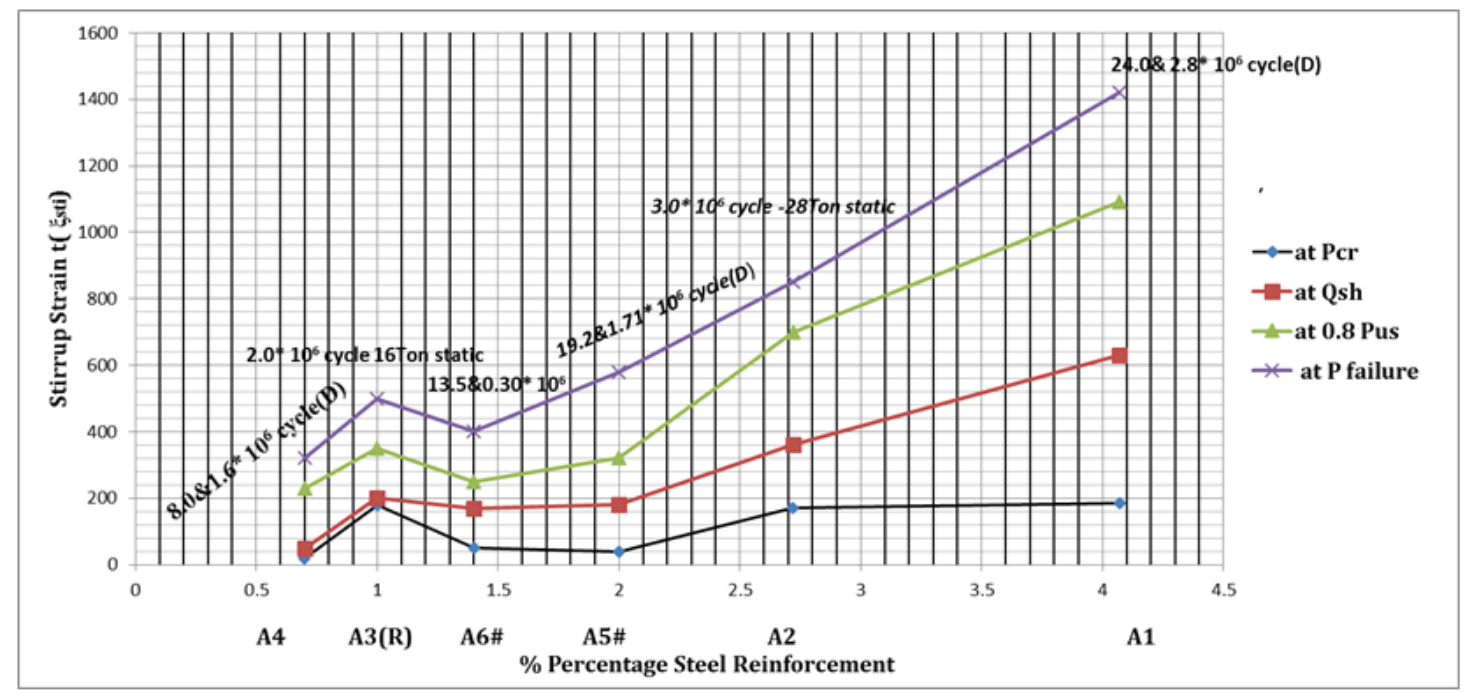

Fig.(14) Relationship between Stirrup Strain- \% Percentage Steel Reinforcement.

\section{4-2-3-2 Steel strain $\left(\varepsilon_{\mathrm{s}}\right)$}

From fig (15) the steel strain relationship with $(\mu \%)$ is affected by the amount of steel .The trend of steel strain at all levels of loading is to be the same and the greatest values seems to be at the case of beam $\overline{\mathrm{A}}_{3(\mathrm{R})}$ $(\mu=1 \%)$ which consider the reference beam. This means that the used steel amount of under reinforced is more effective and steel reached to the yielding point which leading to useful using of high steel grades.

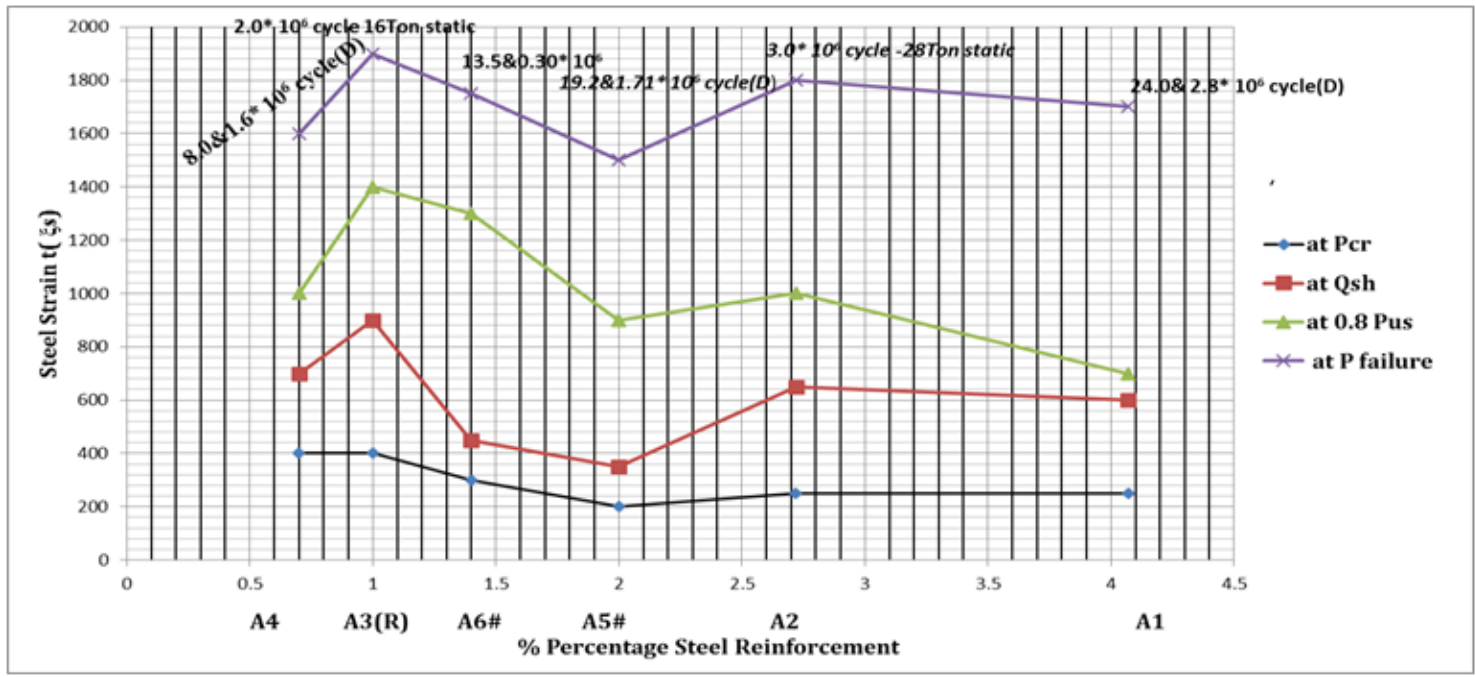

Fig.(15) Relationship between Steel Strain- \% Percentage Steel Reinforcement. 


\section{4-2-3-3 Concrete strain $\left(\left(\varepsilon_{c}\right)\right.$}

Fig.(16), indicated that the max. Concrete compressive strain were considerably affected by the $\%$ percentage of steel reinforcement. The concrete compressive strain is more pronounced for reference beam $\bar{A}_{3(\mathrm{R})}$ $(\mu=1 \%)$ than that other beams having high \% percentage of tension steel reinforcement or by welded mesh (W.M\#).

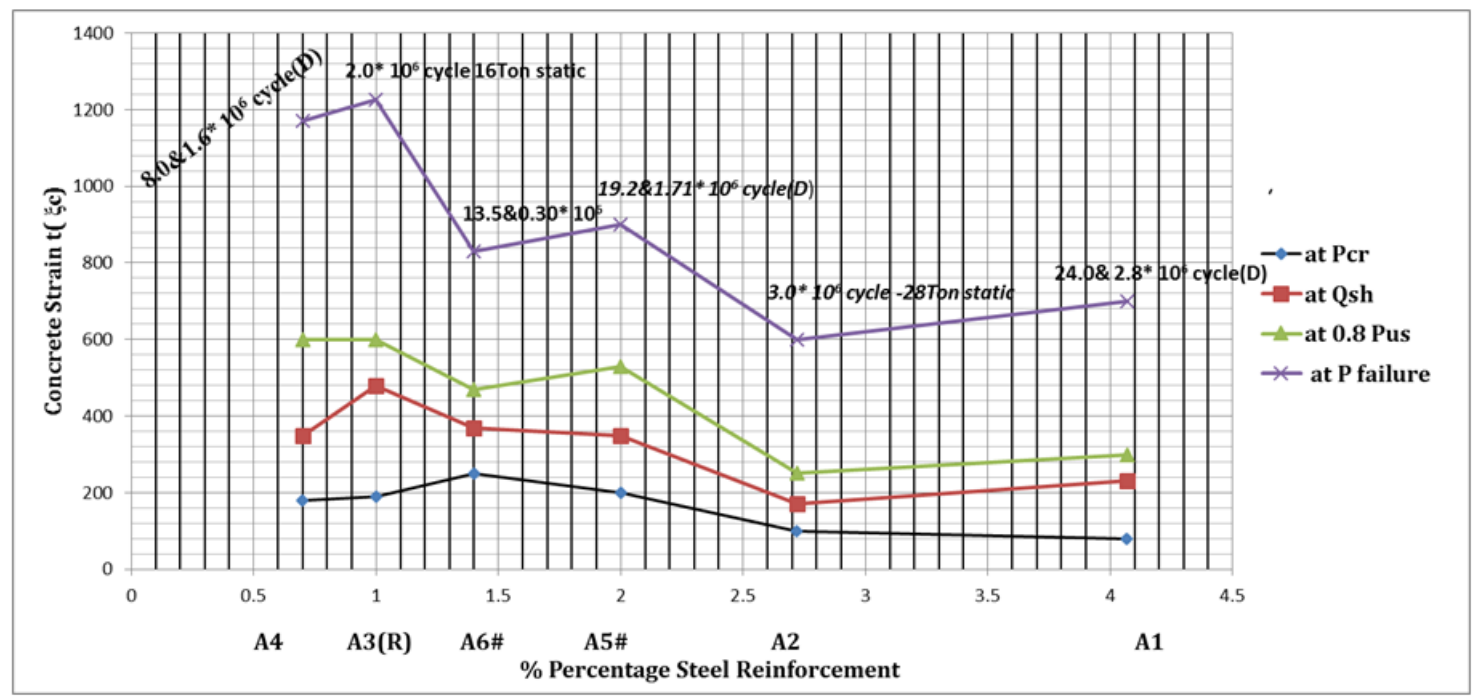

Fig.(16) Relationship between Steel Strain- \% Percentage Steel Reinforcement.

\section{4-2-4 cracking load \& ultimate load}

Values of cracking loads, initial flexural crack load $\left(\mathrm{p}_{\mathrm{cr}}\right)$, shear crack load $\left(\mathrm{Q}_{\mathrm{cr}}\right)$ and ultimate load $\left(\mathrm{p}_{\mathrm{u}}\right)$, for different beams are listed in table (5).

Fig. (17), shows that the cracking load $\left(\mathrm{p}_{\mathrm{cr}}\right)$ increases with the increase of steel percent about $(\mu=2 \%$ balanced section) and the value is to be the same until $(\mu=2.72 \%)$ but with slightly increases for over reinforced section $(\mu=4.07 \%$ ).By increasing the ratio of horizontal web reinforcement (W.M \#12/10) of the beams significantly increases the cracking load.

Table (5): Cracking and Ultimate Loads of Beams:

\begin{tabular}{|c|c|c|c|c|c|c|c|c|c|c|c|c|c|c|}
\hline Beam & Bar & $A_{s}$ & $\boldsymbol{\mu} \%$ & $\mathrm{As}^{\prime}$ & $\alpha=\frac{A_{s^{\prime}}}{}$ & $\mathrm{A}_{s}$ & $\begin{array}{c}\mathrm{A}_{\mathrm{s}} \\
\text { total }\end{array}$ & $P_{c r}$ & $Q_{s r}$ & $\begin{array}{c}0.8 \mathrm{P} \\
\text { us }\end{array}$ & $P_{F}$. & $\mathrm{P}_{\mathrm{cr}}$ & $Q_{s r}$ & $0.8 \mathrm{P}_{\mathrm{us}}$ \\
\hline Type & $\mathrm{m} \cdot \mathrm{m}$ & - III & & & $\lambda_{\mathrm{S}}$ & & $\begin{array}{c}A_{s} \\
\text { (ref) }\end{array}$ & Ton & Ton & Ton & Ton & $\begin{array}{l}\boldsymbol{P}_{c r} \\
(\boldsymbol{R})\end{array}$ & $\begin{array}{l}Q_{c r} \\
(\boldsymbol{R})\end{array}$ & $\begin{array}{c}0.8 \boldsymbol{P}_{u s} \\
(\boldsymbol{R})\end{array}$ \\
\hline$\overline{\mathrm{A}}_{1}$ & $4 \Phi 25$ & 18.4 & 4.07 & 2.26 & 0.123 & 20.64 & 3.0 & 8.0 & 12.0 & 24.0 & $\begin{array}{c}24.0 \& 2.8^{*} \\
10^{6} \\
\text { cycle }(D) .\end{array}$ & 2.0 & 1.2 & 1.875 \\
\hline$\overline{\mathrm{A}}_{2}$ & $4 \Phi 20$ & 12.3 & 2.72 & 2.26 & 0.18 & 14.56 & 2.15 & 6.0 & 12.0 & 22.0 & $\begin{array}{c}3.0^{*} 10^{6} \\
\text { cycle - } \\
28 T o n \\
\text { static }\end{array}$ & 1.5 & 1.2 & 1.72 \\
\hline$\overline{\mathrm{A}}_{3(\mathrm{R})}$ & $4 \Phi 12$ & 4.5 & 1.0 & 2.26 & 0.50 & 6.78 & 1.0 & 4.0 & 10.0 & 12.8 & $\begin{array}{c}2.0^{*} 10^{6} \\
\text { cycle } \\
16 T o n \\
\text { static }\end{array}$ & 1.0 & 1.0 & 1.0 \\
\hline$\overline{\mathrm{A}}_{4}$ & $4 \Phi 10$ & 3.1 & 0.7 & 1.57 & 0.50 & 4.71 & 0.7 & 4.0 & 8.0 & 8.00 & $\begin{array}{c}8.0 \& 1.6^{*} \\
10^{6} \\
\text { cycle }(D) .\end{array}$ & 1.0 & 0.80 & 0.625 \\
\hline$\overline{\mathrm{A}}_{5} \#$ & $12 / 10$ & 9.0 & 2.0 & 4.47 & 0.50 & 13.51 & 2.0 & 6.0 & 12.0 & 19.2 & $\begin{array}{c}19.2 \& 1.71 \\
* 10^{6} \\
\text { cycle }(D) .\end{array}$ & 1.5 & 1.2 & 1.5 \\
\hline$\overline{\mathrm{A}}_{6} \#$ & $10 / 0$ & 36. & 1.4 & 3.14 & 0.50 & 9.42 & 1.4 & 4.0 & 12.0 & 13.5 & $\begin{array}{c}13.5 \& 0.30 \\
=10^{6} \\
\text { cycle }(D) .\end{array}$ & 1.0 & 1.2 & 1.125 \\
\hline
\end{tabular}

(R)-Reference Beam (W.M. \#) Mesh Reinforcement

(S) Static Failure

(D) Daynamic Failure. 


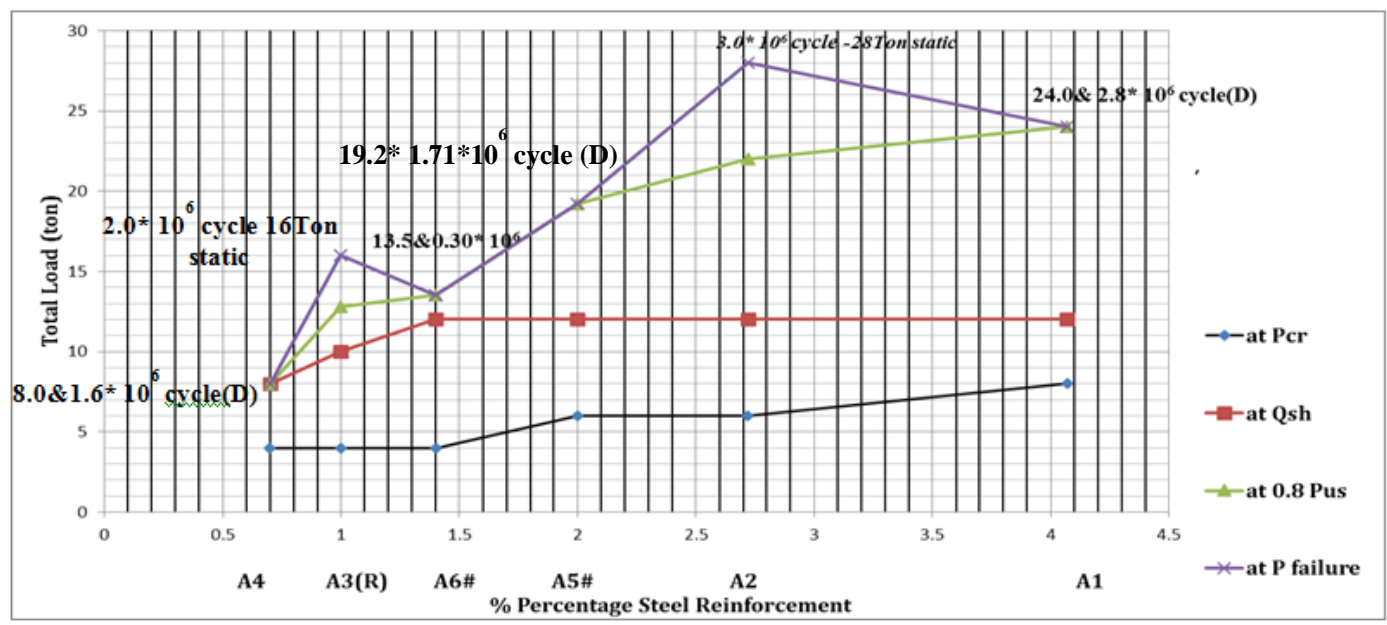

Fig.(17) Relationship between Total Load- \% Percentage Steel Reinforcement ratio.

Using welded mesh (W.M.\#) reinforcement increases the shear cracking load( $Q_{\text {cr. }}$ ) than that for reference beam $\left(\overline{\mathrm{A}}_{3(\mathrm{R})}\right) \quad(\mu=1 \%)$ and become to be the same for beams having high \% percentage of tension steel which balanced or over reinforced section .

The values of the ratio of the flexural cracking load for tested beams comparing with the reference beam $\left(\overline{\mathrm{A}}_{3(\mathrm{R})}\right) \mathrm{p}_{\text {cr } /} \mathrm{p}_{\mathrm{cr} \circledast}$ indicated that :

$200 \%$ for beam $\bar{A}_{1}(4 \phi 25 \mathrm{~mm}----\mu=4.07 \%)$

$150 \%$ for beam $\bar{A}_{2}(4 \phi 20 \mathrm{~mm}----\mu=2.72 \%)$

$150 \%$ for beam $\overline{\mathrm{A}}_{5} \#$ (mesh $\left.\# 12 / 10-\mu=2.0 \%\right)$

$100 \%$ for beam $\bar{A}_{6} \#($ mesh $\# 10 / 10--\mu=1.4 \%)$

$100 \%$ for beam $\overline{\mathrm{A}}_{4}(4 \phi 10 \mathrm{~mm}----\mu=0.7 \%)$

The values of the ratio of the cracking shear load for the tested beams comparing with the reference beam $\left(\overline{\mathrm{A}}_{3(\mathrm{R})}\right) \mathrm{Q}_{\text {cr }} / \mathrm{Q}_{\mathrm{cr} \circledast}$ indicated that:

$120 \%$ for beam $\bar{A}_{1}(4 \phi 25 \mathrm{~mm}----\mu=4.07 \%)$

$120 \%$ for beam $\overline{\mathrm{A}}_{2}(4 \phi 20 \mathrm{~mm}----\mu=2.72 \%)$

$120 \%$ for beam $\bar{A}_{5} \#($ mesh $\# 12 / 10-\mu=2.0 \%)$

$120 \%$ for beam $\bar{A}_{6} \#($ mesh $\# 10 / 10--\mu=1.4 \%)$

$80 \%$ for beam $\overline{\mathrm{A}}_{4}(4 \phi 10 \mathrm{~mm}-----\mu=0.7 \%)$

These values show that the using of welded mesh (W.M.\#) reinforcement enhancement the shearing capacity of beams and it can be used in the design of R.C.sections. The values of the ratio $0.8{ }^{\mathrm{P}} / 0.8 \mathrm{P}_{\mathrm{U} \odot \text {. }}$ of the ultimate load for tested beams comparing with the reference beam $\left(\overline{\mathrm{A}}_{3(\mathrm{R})}\right)$ which failed at $2.0^{*} 10^{6}$ cycle $16 \mathrm{Ton}$ (static).

indicated that :

$187.5 \%$ for beam $\overline{\mathrm{A}}_{1}(4 \phi 25 \mathrm{~mm}--\mu=4.07 \%)$ failed at 24.0 Ton \& $2.8^{*} 10^{6}$ cycle(D)

$172 \%$ for beam $\overline{\mathrm{A}}_{2}(4 \phi 20 \mathrm{~mm}----\mu=2.72 \%) \quad 28.0$ Ton $\& 3.0^{*} 10^{6}$ cycle $-($ static $)$

$150 \%$ for beam $\bar{A}_{5} \#($ mesh $\# 12 / 10-\mu=2.0 \%) \quad 19.20$ Ton $\& 1.71 * 10^{6}$ cycle(D)

$112.5 \%$ for beam $\overline{\mathrm{A}}_{6} \#($ mesh $\# 10 / 10-\mu=1.4 \%) \quad 13.50$ Ton $\& 0.30^{*} 10^{6}$ cycle(D)

$80 \%$ for beam $\overline{\mathrm{A}}_{4}(4 \phi 10 \mathrm{~mm}---\mu=0.7 \%) \quad 8.00$ Ton $\quad \& 1.6^{*} 10^{6}$ cycle(D)

The analysis of the results for the ultimate loads was found to be significantly affected by the $\%$ percentage of steel reinforcement in concrete section. The beam ultimate load carrying capacity increased rapidly by increasing steel percent, but the mode of failure were different according to the type of reinforcement as mentioned above in the crack pattern.

In a reinforced concrete beams reinforced by welded mesh (W.M.\#) reinforcement increase the shear strength due to the presence of horizontal bars which carries a part of horizontal component of the diagonal tension force hence the strength of a beam ought to be greater than of a corresponding beam without additional horizontal bars. This means that the using of horizontal web reinforcement (W.M.\#) appears have higher influence on the cracking and ultimate strength. 
The using of orthogonal system of web reinforcement in the form of welded mesh (W.M.\#) considered to be effective, but the use of U-stirrups alone might not always prevent shear failure, although they would give a high ultimate strength of the beams.

\section{Conclusion}

1. Deformed welded mesh (W.M.\#), reinforcement significantly improves the control of cracking and mode of failure than an equivalent amount of main steel reinforcement exactly under repeated loading. But the using of high \%percentage of steel reinforcement resulting from large bar diameter does not improve the flexural and shear cracking capacity of R.C. beams.

2. The smaller crack indicates the improved bond performance of the smaller deformed diameter (W.M.\#), which led to a larger number of smaller cracks. However the beams reinforced by main longitudinal steel eventually developed larger cracks than they, are reinforced by (W.M.\#). These crack patterns indicate that the (W.M.\#), reinforcement was capable of redistributing the stresses in the shear span without preventing the brittle mode of failure.

3. Welded mesh (W.M.\#), reinforcement further improves the performance of an anchoring and augments crack control. The mode of failure for tested beams is affected by the percentage of steel reinforcement $(\mu \%)$ and welded mesh (W.M.\#) reinforcement.

4. The using of welded mesh (W.M.\#) reinforcement enhancement the ability of the reinforced concrete beams to be deflected more than other beams reinforced by main steel in tension zone in all cases of beams. This attributed to the using of welded mesh (W.M.\#) reinforcement increasing the ductility of beams.

5. AT the support zones in the beams, the used welded transverse wires interrupt the free transfer of stresses from steel to concrete. It may be assumed that these welded transverse wires act as rigid joints that do not allow movement of steel relative to concrete and localized deformation. Hence, any local crushing of the concrete at points of intersection of the main and transverse wires is ignored.

6. The slip for steel reinforcement is increased by decreasing \% percentage of steel reinforcement. This attributed to the bond action between steel reinforcement and concrete is more enough for over and balanced reinforced section $(\mu>2 \%)$ rather than under reinforced section $\quad(\mu<2 \%)$.

7. The strains in the stirrups will be higher when a diagonal crack crosses them, because the diagonal crack can be considered as yield line. The stirrup strain information can be used as an indicator of the degree of contribution of stirrup reinforcement as these locations.

8. The steel strain had the greatest values at the case of beam $\bar{A} 3(\mathrm{R})(\mu=1 \%)$, which consider the reference beam. This means that the used steel amount of under reinforced is more effective and steel reached to the yielding point which leading to useful using of high steel grades.

9. The concrete compressive strain is more pronounced for reference beam $\bar{A} 3(\mathrm{R})(\mu=1 \%)$ than other beams having high \% percentage of tension steel reinforcement or by welded mesh (W.M.\#) reinforcement type.

10. In beams reinforced by welded mesh (W.M.\#) reinforcement, the shear strength increases to the presence of horizontal bars which carries a part of horizontal component of the diagonal tension force hence the strength of a beam ought to be greater than of a corresponding beam without additional horizontal bars. This leads to the using of horizontal web reinforcement (W.M.\#) appears have higher influence on the cracking and ultimate strength.

11. The using of orthogonal system of web reinforcement in the form of welded mesh (W.M.\#) considered to be effective, but the use of U-stirrups alone might not always pervent shear failure, although they would give a high ultimate strength of the beams.

12. Welded mesh (W.M.\#) when used as reinforcement in beams, enhanced the flexural behavior of the beams by distributing the forces along the section.

$\square$ It can be observed that, the first crack and ultimate strength increases up to (50\%\&0.0\%) and $(50 \% \& 12.5 \%)$ respectively with the use of welded mesh(W.M.\#).

$\square$ Compared to the control beam $\square \mathbf{3 ( R )}$, the ultimate load increased by,50\%and $12.5 \%$ for beams $\overline{\mathrm{A}}_{5} \#$ and $\overline{\mathrm{A}}$ ${ }_{6} \#$ respectively.

$\square \quad$ The use of welded mesh(W.M.\#) have made a significant effect on crack pattern of the reinforced concrete beams by delaying the crack appearance, increasing the number of crack and reducing the crack width. 
The ultimate moment capacity for the beam specimens have considerably improved with the use of Welded mesh (W.M.\#).

\section{References}

[1]. Leonhardt, f., and Walther ,R.,'Welded Wire Mesh as Stirrup Reinforcement - Shear Tests on T-Beams and AnchorageTests,'Die Bautechnik(Berlin), V.42, Oct.1965 (in German ,English, translation by W.Dilger ).

[2]. CEB-FIP Manual.: Technology and Industrialization of Reinforcement Part two: Reinforcement for reinforced concrete. November 1979.

[3]. Taylor, M.A,.H and EL-Hammasi, S.. "Web Cracking Behavior of Beams Using Welded Wire Fabric as Shear Reinforcement". ACI journal, proceedings V.77,.No 1, Jan - Feb .1980, pp.12-17.

[4]. Mansur .M.A, Lee, C.k, and Lee S.L." Deformed Wire Fabric as Shear Reinforcement in Concrete Beams."ACI Journal, V.84, NO.5, Sept Oct.1987, pp.392-399.

[5]. Pincheira, J.A, Rizkalla, S.Hand Attiogbe, E "Welded Wire Fabric as Shear Reinforcement under Cyclic Loading “ Proceedings, 1988 CSCE Annual conference, May, 1988, pp. 643-663

[6]. Griezic, A. ,Cook,W.and D.,Mitchell Denis .Tests to Determine Performed Welded Wire Fabric Stirrups .ACI Structural Journal ,V.91,No.2,Mar.-Apr.1994.pp.211-220.

[7]. Ayyub, B. M., Mutairi, N.and Chang, P. .’Bond Strength of Welded Wire Fabric in Concrete Bridge Decks.”Journal of Structural Engineering V. 120, No. 8, Aug .1994.pp. 2520-2531.

[8]. AASHTO LRFD Bridge Design Specifications and Commentary $1^{\text {st }}$ Edition, American Association of State Highway and Transportation Officials, Washington, D.C, 1994, 1091 pp.

[9]. CSA Committee A23.3, Design of Concrete Structures: (Structures Design) -A National Standard of Canada, Canadian Standards Association, Rexdale, Dec.1994, 199PP.

[10]. .10-ACI Committee 318,"Building Code Requirements for Structural Concrete (ACI 318-95) and Commentary (318-R95)"American Concrete Institute, Farmington Hills, Mich., 1995, 369 pp.

[11]. -CHBDC Committee, Canadian Highway Bridge Design Code, $1^{\text {st }}$ Editiom , 1996

[12]. Adebar, p.. and Leeuwen, j"Side-face Reinforcement for Flexural and Diagonal Cracking in Large Concrete Beams."ACI Structural Journal/ V.96,No.5, September-October 1999 .pP 693-704

[13]. Aly Abdel-Zaher Elsayed BEHAVIOUR OF REINFORCED CONCRETE T. BEAMS WITH WELDED MESH REINFORCEMENT Bulletin of the Faculty of Engineering,Assiut University, Vol.29,NO. 1, PP.109-125,JAN..2001.

[14]. Masoud Soltania, Xuehui An, Koichi Maekawa, Cracking response and local stress characteristics of RC membrane elements reinforced with welded wire mesh, Cement \& Concrete Composites, 2004, 26,389-404.

[15]. Hani H. Nassif and Husam Najm, Experimental and Analytical Investigation of Ferrocement-Concrete Composite Beams, cement and concrete composites, 2004, 26, 787-796.

[16]. Noor Ahmed Memon, lihuddinRadinSumadi,MahyuddinRamli, Ferrocement encased light weight aerated concrete :A novel approach to produce sandwich composite, Materials Letters, 2007, 61, 4035-4038.

[17]. Hassan Mohamed Ibrahim, Experimental investigation of ultimate capacity of wired mesh-reinforced cementitious slabs, Construction and Building Materials, 2011, 25, and 521-259.

[18]. Naveen.G.M. and Suresh.G.S., Experimental study on light weight ferrocement beam under monotonicand repeated flexural loading, International Journal of Civil and Structural Engineering, 2012, 3, 294-301.

[19]. Ismail M.I. Qeshta, Payam Shafigh, Mohd ZaminJumaat, Aziz Ibrahim, Ubagaram Johnson Alengaram, The Use of Wire MeshEpoxy Composite for Enhancing the Flexural Performance of Concrete Beams,Materials and Design, 2014, 60, 250-259.

S.Prathima, P. Jaishankar, Experimental Investigation of Wired Mesh - RC Beam International Journal of Chem -Tech Research CODEN (USA): IJCRGG ISSN: 0974-4290 Vol.8, No.2, pp 815-821, 2015 20. IS 456 - 2000, Indian Standard PLAIN AND REINFORCED CONCRETE - CODE OFPRACTICE, Bureau of Indian Standard, Manak Bhavan, 9 Bahadur Shah Zafar Marg, New Delhi110002.

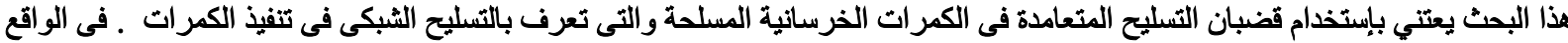

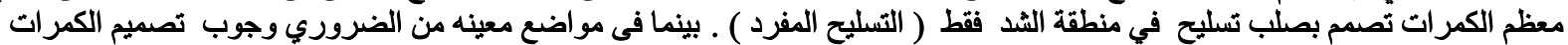

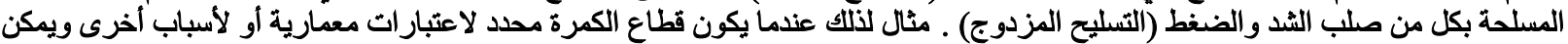

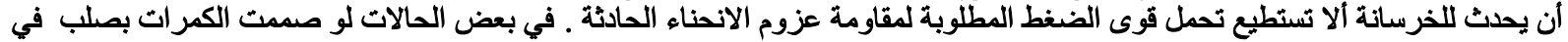

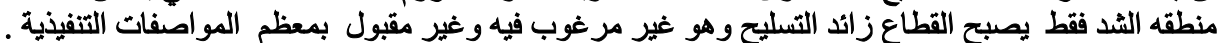

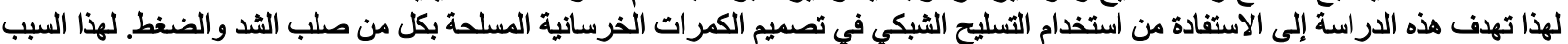
تم إعداد وصسب عدد(6) ستة كمرات بنسبة تسليح رئيسي زائد (

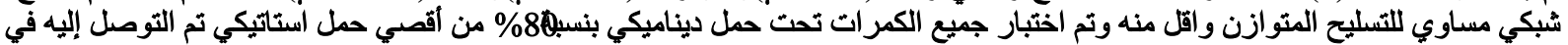
بحث سابق( 13 ) آخذ في الاعثبار نسبة صلب التسليح في القطاع الخرساني للكمرات. وقد تم عرض نتائج البحث للتعرف على سلى سلوك مثل هذا

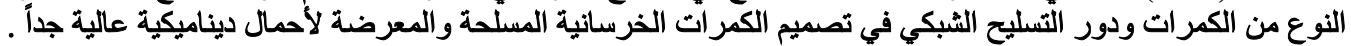

